\title{
1 Identification of novel leaf rust seedling resistance loci in Iranian bread wheat germplasm using genome-wide
} 2 association mapping

\section{Abstract}

4 Leaf or brown rust caused by Puccinia triticina Eriks. (Pt) is a major biotic constraint threatening bread wheat 5 production worldwide. The continued evolution of new races of $P t$ necessitates a constant search for the 6 identification of new resistance genes, or QTLs, to enhance the resistance durability of bread varieties. On a panel of 7320 bread wheat accessions, we used a genome-wide association study (GWAS) technique to map loci associated 8 with $P t$ resistance using single-nucleotide polymorphism markers (SNPs) generated by genotyping-by-sequencing (GBS). The panel was tested with five $P t$ races gathered from different regions of IRAN to identify loci associated with seedling resistance. After estimating genetic relatedness and population structure among accessions, GWAS discovered a total of 19 SNPs on chromosomes 1B, 2B, 3A, 3B, 4A, 5B, 5D, 6A, 6B, 6D, 7B, and 7D that were significantly associated with seedling stage resistance. The three SNP markers rs12954, rs34220, and rs42447 on chromosomes 5D, 6A, and 7D, respectively, associated with resistance to $P t$ race PKTTS expressing potential new loci for leaf rust resistance. Overall, this research gives an integrated perspective of leaf rust resistance resources in Iranian bread wheat and recognizes new resistance loci that will be valuable to expand the set of resistance genes available to control this serious disease.

17 Keywords: Wheat, Puccinia triticina (Pt), GWAS, MATs, $L r$ genes 


\section{Introduction}

Common wheat (Triticum aestivum L.) is among the most important and widely consumed food crops worldwide, and one of the most traded commodities on global markets (FAO 2020). Wheat is frequently attacked by a variety of diseases. Leaf rust caused by Puccinia triticina Eriks. (Pt), the most prevalent and serious foliar disease impacting wheat production globally, is one of the diseases that causes considerable yield losses in bread wheat (Kolmer 2019; Dinh et al. 2020). In highly susceptible cultivars, the leaf rust fungus mostly affects the leaf blades, but it can also attack the leaf sheath and glumes. Yield loss is usually caused by the reduction of kernel weight and kernel number per spike (Huerta-Espino et al. 2011; Figueroa et al. 2018).

Although fungicides are effective to control rust diseases, using resistant cultivars is more effective, cost-effective, and environmentally safe (Chen, 2020). As a result, having adequate information on the leaf rust agent's population genetics and identifying novel sources of resistance in the cultivated and landrace gene pools of wheat to contribute to expanding and sustaining the genetic base of leaf rust resistance is critical (McInosch et al. 2013). Plant disease resistance genes can be categorized into two types: all-stage resistance (seedling resistance) and adult-plant resistance (APR). Seedling resistance, which is often race-specific, expresses at all stages of plant development and is commonly associated with a strong hypersensitive reaction with a high level of resistance, despite being easily broken down by changes in rust pathogen virulence. On the other hand, APR that also known as race nonspecific resistance is more effective at adult stages of plant development and is effective against all $P t$ races, and is durable. Many wheat cultivars have become susceptible because of the continual emergence of new pathogen races with new virulence. As a result, new sources of resistance and new Leaf rust ( Lr) resistance genes must be discovered to manage this significant wheat disease (Kolmer et al. 2013; Dinh et al. 2020). Until today a total of $80 \mathrm{Lr}$ genes (Leaf Rust Gene) have been discovered (Qureshi et al. 2018; McIntosh et al. 2013; Kumar et al. 2021). The majority of these genes confer seedling resistance, however, nine slow-rusting genes, namely Lr34 (Dyck 1977), Lr46 (Singh et al. 1998), Lr67 (Herrera-Foessel et al. 2014), Lr68 (Herrera-Foessel et al. 2012), Lr74 (McIntosh et al. 2013 ), Lr75 (Singla et al. 2017), Lr77 (Kolmer et al. 2018), Lr78 (Kolmer et al. 2018), and Lr79 (Qureshi et al. 2018) govern adult plant resistance.

Although bi-parental mapping was successful to discover genomic loci for leaf rust resistance, the restricted recombination events in bi-parental mapping limited the discovery of closely related markers valuable for MAS because of the long linkage block (Riedelsheimer et al. 2012). The genome-wide association study (GWAS) is the most recent methodological technique, which relies on the linkage disequilibrium (LD) principle and the utilization of many SNP (Single Nucleotide Polymorphism) markers. GWAS identifies associations between phenotyping and genotyping data in an association mapping population, and it provides complete surveys of germplasm pools and is a valuable complement to bi-parental mapping research (Zargar et al. 2015; Tibbs Cortes et al. 2021). GWAS utilizes the recombination events that happen during the evolution of populations. This provides the breakup of the LD blocks within the genome and results in a faster decay of the LD in the association mapping than in RILs (recombinant inbred lines) and DH (double haploid) populations, in which only the allelic diversity that separates between the parents can be evaluated. Therefore, GWAS can distinguish associated loci with the trait response at a much higher mapping resolution than bi-parental mapping (Rafalski 2002; Nordborg and Weigel 2008 ; Zhao et al. 2008; Neumann et al. 2011).

The GWAS method has been successfully applied in different plants for various traits. Different wheat traits have been studied using GWAS including agronomic traits (Safdar et al. 2020; Pang et al. 2020), quality (Yang et al. 2020; Muqaddasi et al. 2020), drought stress (Abou-Elwafa et al. 2021; Shokat et al. 2020; Rahimi et al. 2019), leaf rust (Spakota et al. 2019; Muqaddasi et al. 2021), and stem rust resistance (Saremi et al. 2021; Gao et al. 2017). For leaf rust resistance, Spakota et al. (2019) employed GWAS to identify related genomic areas in wheat genotypes, and eleven QTLs (Quantitative Trait Loci) were identified on nine chromosomes. In wheat landraces, Kertho et al. (2015) observed 73 QTLs associated with resistance to leaf rust and strip rust, and 11 of them were regarded as novel. Also, Gao et al. (2016) discovered 46 QTLs associated with seedling and adult stage resistance for resistance to leaf rust, and about $30 \%$ of the phenotypic variance was explained by the ten most significant QTLs. 
In the present study, GWAS was conducted on a diverse panel of wheat cultivars and landraces originating from several geographical areas in Iran. This study was designed to detect genetic loci related to seedling resistance to leaf rust by use of 320 Iranian wheat accessions against five $P t$ races, which will be used in markerassisted selection and further genetic dissections.

\section{Materials and methods}

Plant materials and $P t$ races

A leaf rust association mapping (AM) panel of 320 wheat accessions was used in the present study, which includes 102 varieties released between 1942 and 2014 and 218 landraces collected between 1931 and 1968 (Supplementary Table 1), along with the susceptible cultivar Boolani. Commercial cultivars were received from the Seed and Plant Improvement Institute (SPII), Karaj, Alborz, Iran, and landraces from the University of Tehran's Gene Bank. For 298 accessions, both phenotypic and genotypic data were available (90 varieties and 208 landraces).

The five $P t$ races PKTTS, PKTTT, PFTTT, PDTRR, and PDKTT, representing prevalent races of $P t$ in IRAN, were used to screen the wheat accessions. All isolates were collected from bread wheat germplasm. The virulence/avirulence profile of the rust races was determined using infection types based on the seedling stage of Thatcher wheat differentials that are near-isogenic for single-resistance genes based on the race nomenclature of Long and Kolmer (1989). The characteristics of used races are presented in Table 1.

Table 1. Virulence/avirulence profile the five $P t$ races used to evaluate the wheat genotypes

\begin{tabular}{|c|c|c|c|c|}
\hline No & Race & Location & Ineffective genes & Effective genes \\
\hline 1 & PKTTT & Dezfoul_Khouzestan & $\begin{array}{l}\text { Lr22b, Lr1, Lr2c, Lr3, Lr3ka, Lr3bg, } \\
\text { Lr10, Lr11, Lr12, Lr13, Lr14a, Lr14b, } \\
\text { Lr15, Lr16, Lr17, Lr18, Lr20, Lr21, } \\
\text { Lr22a, Lr23, Lr24, Lr25, Lr26, Lr10, } \\
\text { Lr27+Lr31, Lr28, Lr30, Lr32, Lr33, } \\
\text { Lr34, Lr35, Lr36, Lr37, Lrb, Lr13 }\end{array}$ & Lr2a, Lr2b, Lr9, Lr19, Lr29 \\
\hline 2 & PFTTT & Dezfoul_Khouzestan & $\begin{array}{l}\text { Lr22b, Lr1, Lr2b, Lr2c, Lr3, Lr3ka, } \\
\text { Lr3bg, Lr10, Lr11, Lr12, Lr13, Lr14a, } \\
\text { Lr14b, Lr17, Lr18, Lr20,Lr21, Lr22a, } \\
\text { Lr23, Lr24, Lr25, Lr26, Lr28, Lr30, Lr32, } \\
\text { Lr33, Lr34, Lr35, Lr36, Lr37, Lrb, Lr13 }\end{array}$ & $\begin{array}{l}\operatorname{Lr2a}, \operatorname{Lr} 9, \operatorname{Lr} 15, \operatorname{Lr} 16, \operatorname{Lr} 19 \\
\operatorname{Lr} 10, \operatorname{Lr} 27+\operatorname{Lr} 31, \operatorname{Lr} 29\end{array}$ \\
\hline 3 & PKTTS & Moghan_Ardabil & $\begin{array}{l}\text { Lr22b, Lr1, Lr2c, Lr3, Lr3ka, Lr3bg, } \\
\text { Lr10, Lr11, Lr12, Lr13, Lr14a, Lr14b, } \\
\text { Lr15, Lr16, Lr17, Lr18, Lr20, Lr21, } \\
\text { Lr22a, Lr23, Lr24, Lr25, Lr26, Lr10 / } \\
\text { Lr27 + / Lr31, Lr29, Lr30, Lr32, Lr33, } \\
\text { Lr34, Lr35, Lr36, Lr37, Lrb, Lr13 }\end{array}$ & Lr2a, Lr2b, Lr9, Lr19, Lr28 \\
\hline 4 & PDKTT & Ahwaz_Khouzestan & $\begin{array}{l}\text { Lr22b, Lr1, Lr2c,Lr3, Lr3bg, Lr10,(Lr10, } \\
\text { Lr27+Lr31), Lr11, Lr12, Lr13, Lr14a, } \\
\text { Lr14b, Lr15,Lr16, Lr17, Lr18, Lr20, } \\
\text { Lr21, Lr22a, Lr23, Lr24,Lr25, Lr28, } \\
\text { Lr30, Lr32, Lr33, Lr34, Lr35, Lr36, Lr37, } \\
\text { Lrb }\end{array}$ & $\begin{array}{l}\text { Lr2a, Lr2b, Lr3ka, Lr9, } \\
\text { Lr16, Lr19, Lr26, (Lr10, } \\
\text { Lr27+Lr10), Lr29 }\end{array}$ \\
\hline 5 & PDTRR & Gorgan_Golestan & $\begin{array}{l}\text { Lr22b, Lr 1, Lr2a, Lr2b, Lr3ka, Lr9, } \\
\text { Lr10, Lr11, Lr14a, Lr16, Lr19, Lr20, } \\
\text { Lr23, Lr26, (Lr10, Lr27+Lr31), Lr28, } \\
\text { Lr29, Lr33, Lr37, Lr13 }\end{array}$ & $\begin{array}{l}\text { Lr22b, Lr2c, Lr3, } \\
\text { Lr3bg,Lr12, Lr13,Lr14b, } \\
\text { Lr15, Lr17, Lr18, Lr21, } \\
\text { Lr22a, Lr24, Lr25, Lr30, } \\
\text { Lr32, Lr34, Lr35, Lr36, Lrb }\end{array}$ \\
\hline
\end{tabular}

Phenotyping at Seedling Stage 
Seven seeds of each accession were sown in pots with a diameter and a height of $10 \mathrm{~cm}$, filled with a mixture of common soil, peat moss, and leaf mold. In each pot, four wheat accessions have been positioned at a suitable distance. Then they were stored on a growth chamber at $22-25^{\circ} \mathrm{C}$ and a $16 \mathrm{~h}$ photoperiod for development. After 810 days, when secondary leaves have emerged, inoculation of the seedlings were done separately by the spores of five rust races gathered from various fields of Iran. Then the inoculated seedlings moved in a dark room for one day at $17 \pm 2{ }^{\circ} \mathrm{C}$ and near $95 \%$ moisture, then they were placed in a growth chamber kept at $18^{\circ} \mathrm{C} / 20^{\circ} \mathrm{C}$ (night/day) with 16-h of photoperiod. The 10-12 days after inoculation, plant infection type (IT) was determined based on the method described by McIntosh et al. (1995) rated a scale of $0-4$ where $0=$ no visible uredia (immune), ; = hypersensitive fleck (very resistant), $1=$ small uredia with necrosis (resistant), $2=$ small- to medium-sized uredia (resistant to moderately resistant), $3=$ medium-sized uredia with or without chlorosis (moderately resistant/moderately susceptible), and $4=$ large-sized uredia without chlorosis (susceptible reaction). The $0-4$ scale for leaf rust was transformed to a linearized 0- 9 scale utilizing the weighted mean of the most and least predominant IT on the same leaf surface to employ the modified McIntosh ITs in genome-wide association studies (GWAS) (Zhang et al. 2014). Values 0 to 6 were considered as resistance IT and, 7 to 9 were considered as susceptible IT.

\section{Genotyping by sequencing and imputation method}

Genotypic evaluation of wheat accessions was conducted in collaboration with the US Ministry of Agriculture and the University of Kansas (Alipour et al. 2017). In brief, genomic DNA of wheat accessions was isolated from young leaves using the modified cetyltrimethyl ammonium bromide (CTAB) method (Saghai-Maroof et al. 1984). The GBS (Genotyping by sequencing) libraries were constructed with two restriction enzymes $P s t \mathrm{I}$ and $M s p \mathrm{I}$ according to the method of Poland et al. (2012). Subsequently, barcoded adapters ligation to individual samples were performed using T4 ligase. The DNA purification was carried out using the QIAquick PCR Purification Kit (Qiagen, Inc., Valencia, CA, USA). Finally, the amplified fragments between 250-300 bp were specified on the E-gel system and sent for sequencing on an Ion Proton sequencer (Life Technologies, Inc.). The sequencing data were first trimmed to $64 \mathrm{bp}$, and the same reads were grouped into tags. The UNEAK GBS pipeline (Lu et al. 2013) as part of the TASSEL 4.0 bioinformatics package (Bradbury et al. 2007) was used for SNPs calling, where SNPs with heterozygosity 10\%>, minor allele frequency (MAF) >0.1, and missing data 20\%> were removed and other SNPs were used for further analysis. The data was also subjected to imputation using BEAGLE v3.3.2 (Browning and Browning., 2009) based on available allele frequencies obtained after specifying the haplotype phase for all individuals. Four different reference genomes were evaluated and among them, the W7984 reference genome was selected to have the greatest annotation accuracy.

\section{Phenotypic data analysis}

Phenotypic data analysis including descriptive analysis, ANOVA (Analysis of Variance), correlation analysis, and heritability estimation was performed using the SAS software v.9.4. The Shapiro-Wilk test (PROC UNIVARIATE) and Levene's test (Snedecor and Cochran 1989) were conducted to determine the normal distribution of phenotypic data and to verify the homogeneity of data between experiments, respectively. For the GWAS analysis, the overall mean was used if the data were homogenous. The genetic, environmental, and phenotypic variances were estimated based on the Comstock \& Robinson (1952) method as follow:

$\sigma_{\mathrm{g}}^{2}=\frac{\mathrm{MS}_{\mathrm{g}}-\mathrm{MS}_{\mathrm{e}}}{\mathrm{r}}$

$\sigma_{\mathrm{e}}^{2}=\mathrm{MS}_{\mathrm{e}}$

$\sigma_{\mathrm{p}}^{2}=\sigma_{\mathrm{e}}^{2}+\mathrm{MS}_{\mathrm{g}}$

Where $\mathrm{MS}_{\mathrm{g}}$ is genotype mean square, $\mathrm{MS}_{\mathrm{e}}$ is error mean square and $\mathrm{r}$ is the number of experimental repetitions. The broad-sense heritability for leaf rust was calculated via the ratio of genetic variance to phenotypic variance as follow:

$\mathrm{H}^{2}=\frac{\sigma_{\mathrm{g}}^{2}}{\sigma_{\mathrm{g}}^{2}+\sigma_{\mathrm{e}}^{2}}$ 
Pearson correlation coefficients among races were determined for IT values based on PROC CORR procedure in SAS software.

\section{Population structure and LD}

To apprehend the genetic structure of the population of Iranian wheat genotypes and to recognize subpopulations, we used Bayesian methods using STRUCTURE v2.3.3 (Pritchard et al. 2000). A putative range of subpopulations starting from $\mathrm{k}=1$ to 10 was assessed using an admixture model and with a burn-in and simulation phase consisting of 30,000 steps. An adhoc statistic based on the rate of change of the log-likelihood of the data between successive values was used to estimate K. (Evanno et al. 2005; Quraishi et al. 2011). LD between markers was estimated by comparing of observed vs. expected allele frequencies of the markers in TASSEL v.5.2.65 (Bradbury et al. 2007). A Kinship matrix ( $Q$ matrix) among individual genotypes for association studies was estimated using all SNP markers; the heat map was performed with the use of a classical equation from Van Randen (2008) in the R software. Principal Component Analysis (PCA) was done by use of SNP markers to specify the genetic relationships between the genotypes, and PC1 was plotted against PC2.

\section{Genome- wide association mapping}

A dataset including 298 accessions was obtained after combining phenotypic (320) and genotypic data (298). GWAS to discover marker-trait associations (MTAs) significantly with seedling resistance was performed using general linear model (GLM) and mixed linear model (MLM) using TASSELv.5.2.65 (Bradbury et al. 2007) and showed that the GAPIT package (Lipka et al. 2012) supplied stronger control confounding effects. Therefore, only GAPIT results were reported (Lipka et al. 2012). MTAs with a LOD (Logarithm of the Odds) score above 3 (p-value 0.001) were selected as significant markers for leaf rust resistance. FDR (False Discovery Rate) at the alpha level of 0.05 was used to reduce the false discovery rate of significant markers. In order to reduce the false discovery rate of significant markers, the FDR (False Discovery Rate) was set as 0.05 at the alpha level.

\section{Gene annotation}

The flanking sequences of significant marker-trait associations (MTAs) were received from the Illumina 90K SNP Ensemble plants database (https://plants.ensembl.org/) by aligning them to the IWGSC RefSeq v1.0 annotation (https://plants.ensembl.org/Multi/Tools/Blast\#). The function of the putative genes was determined by examining the metabolic pathways involving the encoded enzymes. The overlapping genes with the highest identity percentage and blast score were selected for further analysis. The information of each gene adjacent to T. aestivum, including molecular function, biological process as well as orthologous genes in related species, were obtained from the ensemble-plants database (https://plants.ensembl.org/).

\section{Comparison QTLs with previously detected $L r$-gene/QTLs}

To discover the relationship between the SNP markers identified that related to leaf rust resistance in this study to previously detected $L r$-gene/QTLs, the positions of the most significant markers (FDR < 0.05) representative of each QTL to previously mapped QTL/genes were compared using wheat consensus map (Maccaferri et al. 2015). The graphical display of the genetic map was constructed using MapChart (Voorrips 2002).

\section{Results}

Phenotypic evaluation

IT response (Infection Type) against five pathotypes (PKTTS, PKTTT, PFTTT, PDKTT, and PDTRR) was evaluated in the greenhouse for 320 accessions. The results are presented in Supplementary Table 2. In all the experiments, the susceptible cultivar Boolani was highly infected and showed the expected compatible ITs of 3 to 4 for all five pathotypes. Wheat accessions had a wide variety of responses to all five $P t$ races used in our research (Supplementary Table 2). The leaf rust scores varied from immune (IT $=0, \mathrm{LS}=0$ ) to highly susceptible reaction 
Table 3. Resistance wheat accessions to all five Puccinia triticina (Pt) races

\begin{tabular}{|c|c|c|c|c|c|c|c|}
\hline & & \multicolumn{5}{|c|}{ Disease score } \\
\hline Accession & Origin & Type & PKTTT & PFTTT & PDKTT & PKTTS & PDTRR \\
\hline 622084 & Mazandaran_Sari & Landrace & 0.70 & 0.70 & 5.33 & 0.70 & 0.70 \\
\hline 622099 & Gilan_Rasht & Landrace & 0.70 & 3.34 & 2.67 & 0.70 & 0.35 \\
\hline 622247 & Mazandaran_Sari & Landrace & 0.70 & 0.70 & 5.33 & 0.35 & 0.67 \\
\hline 622264 & Mazandaran_Babol & Landrace & 0.70 & 2.17 & 1.19 & 1.67 & 0.35 \\
\hline 622272 & Mazandaran_Amol & Landrace & 1.19 & 4.00 & 2.17 & 0.35 & 0.35 \\
\hline 624381 & Bakhtaran_Bakhtaran & Landrace & 0.70 & 1.67 & 4.00 & 0.70 & 0.35 \\
\hline 627856 & Mazandaran_Sari & Landrace & 1.19 & 0.70 & 1.19 & 1.19 & 0.35 \\
\hline 627963 & Hamedan_Hamedan & Landrace & 0.70 & 1.19 & 1.69 & 1.50 & 0.35 \\
\hline 627057 & Gilan_Fooman & Landrace & 2.17 & 1.84 & 7.5 & 2.84 & 0 \\
\hline Shinghai & - & Varity & 6.00 & 4.00 & 7.67 & 7.67 & 0.35 \\
\hline
\end{tabular}

The ANOVA for leaf rust seedling reactions showed highly significant differences $(\mathrm{P}<0.001)$ between races,

(IT=4, LS=9) to all five $P t$ races (Table 2). The majority of the tested wheat accessions were susceptible to the $P t$ races and of these, 36, 32, 59, 38, and 77 accessions were resistant (IT rating < 3, linear score $<8$ ) to races PKTTS, PKTTT, PFTTT, PDKTT, and PDTRR, respectively (Table 2), also a total of ten accessions were resistant to all five pathotypes (Table 3).

The results of the Shapiro-Wilk normality test indicated that the phenotypic data of all five $P t$ pathotypes deviated significantly from a normal distribution (Table 4). The Leven's test was then performed to test the homogeneity of the data. The results of Levene's test indicated that the phenotypic variance of the data within experiments was homogenous ( $\mathrm{P}=0.23$ to 0.79 ) for all five Pt pathotypes (Table 4). Therefore, the overall mean for each wheat accession was calculated and utilized in GWAS study.

Table 2. grouping of wheat population based on infection type to five Pt races

\begin{tabular}{|c|c|c|c|c|c|c|c|c|c|c|c|}
\hline \multirow[b]{2}{*}{ Infection Type } & \multirow{2}{*}{$\begin{array}{l}\text { Cultivar/ } \\
\text { Landrace }\end{array}$} & \multicolumn{2}{|c|}{ PKTTS } & \multicolumn{2}{|c|}{ PKTTT } & \multicolumn{2}{|c|}{ PFTTT } & \multicolumn{2}{|c|}{ PDKTT } & \multicolumn{2}{|c|}{ PDTRR } \\
\hline & & No & $\%$ & No & $\%$ & No & $\%$ & No & $\%$ & No & $\%$ \\
\hline \multicolumn{12}{|l|}{ Resistance reaction } \\
\hline \multirow[t]{2}{*}{0 and ; } & Cultivar & 1 & 0.31 & 3 & 0.94 & 0 & 0 & 0 & 0 & 10 & 3.13 \\
\hline & Landrace & 2 & 0.63 & 0 & 0 & 0 & 0 & 0 & 0 & 6 & 1.88 \\
\hline \multirow[t]{2}{*}{; 1, 1 and $1+$} & Cultivar & 4 & 1.25 & 2 & 0.63 & 1 & 0.31 & 0 & 0 & 15 & 4.69 \\
\hline & Landrace & 6 & 1.88 & 9 & 2.81 & 4 & 1.25 & 2 & 0.63 & 7 & 2.19 \\
\hline \multirow[t]{2}{*}{$; 2,2$ and $2+$} & Cultivar & 2 & 0.63 & 3 & 0.94 & 7 & 2.19 & 0 & 0 & 5 & 1.56 \\
\hline & Landrace & 4 & 1.25 & 1 & 0.31 & 8 & 2.5 & 2 & 0.63 & 4 & 1.25 \\
\hline \multirow[t]{2}{*}{; 123 and $321 ;$} & Cultivar & 14 & 4.38 & 7 & 2.19 & 27 & 8.44 & 14 & 4.38 & 19 & 5.94 \\
\hline & Landrace & 3 & 0.94 & 7 & 2.19 & 12 & 3.75 & 16 & 5 & 8 & 2.5 \\
\hline \multirow[t]{2}{*}{ Total } & Cultivar & 21 & 6.56 & 15 & 4.69 & 35 & 10.94 & 14 & 4.38 & 49 & 15.31 \\
\hline & Landrace & 15 & 4.69 & 17 & 5.31 & 24 & 7.5 & 20 & 6.25 & 25 & 7.81 \\
\hline \multirow[t]{2}{*}{3 and $3+$} & Cultivar & 80 & 25 & 79 & 24.68 & 67 & 20.94 & 87 & 27.19 & 53 & 16.56 \\
\hline & Landrace & 188 & 58.75 & 184 & 57.5 & 190 & 59.38 & 190 & 59.38 & 189 & 59.06 \\
\hline \multirow[t]{2}{*}{4} & Cultivar & 2 & 0.63 & 9 & 2.81 & 1 & 0.31 & 2 & 0.63 & 0 & 0 \\
\hline & Landrace & 14 & 4.34 & 16 & 5 & 3 & 0.94 & 7 & 2.19 & 3 & 0.94 \\
\hline \multirow[t]{2}{*}{ Total } & Cultivar & 82 & 25.63 & 84 & 26.25 & 68 & 21.25 & 89 & 27.81 & 53 & 16.56 \\
\hline & Landrace & 202 & 63.13 & 200 & 62.5 & 193 & 60.31 & 197 & 61.56 & 192 & 60 \\
\hline Total accessions & & 320 & 100 & 320 & 100 & 320 & 100 & 320 & 100 & 320 & 100 \\
\hline
\end{tabular}
accessions, and race $\times$ accession interaction (Table 5). The coefficient of correlation ( $\mathrm{r}$ ) among all five $P t$ pathotypes was highly positive and significant. The correlation coefficient values for ITs ranged from 0.40-0.71. In particular, 
high correlation coefficient values were observed for the pair-correlations of PKTTS vs. PFTTT (0.71), PFTTT vs.

Table 4. Descriptive statistics of 320 wheat accessions evaluated for their response to five Puccinia triticina (Pt)

207

208

209

210

211

212

213

214

215

216

217

218

219

220

\begin{tabular}{|c|c|c|c|c|c|c|c|c|c|c|}
\hline Race & Mean & Min & Max & SD & $\begin{array}{c}\text { Shapiro-Wilk } \\
\text { test }^{\text {a }}\end{array}$ & $\begin{array}{c}\text { Leven's } \\
\text { test }^{\text {b }}\end{array}$ & $\sigma_{g}^{2}$ & $\sigma_{e}^{2}$ & $\sigma_{p}^{2}$ & $\mathrm{H}^{2}(\%)$ \\
\hline PKTTT & 8.30 & 0 & 9.00 & 2.15 & $\mathrm{P}<0.0001$ & $\mathrm{P}=0.595$ & 4.604 & 0.017 & 4.621 & 99.63 \\
\hline PFTTT & 7.92 & 0.70 & 9.00 & 2.00 & $\mathrm{P}<0.0001$ & $\mathrm{P}=0.229$ & 3.835 & 0.394 & 4.23 & 90.67 \\
\hline PKTTS & 8.30 & 0 & 9.00 & 2.06 & $\mathrm{P}<0.0001$ & $\mathrm{P}=0.792$ & 4.173 & 0.115 & 4.29 & 97.34 \\
\hline PDTRR & 7.33 & 0 & 9.00 & 3.12 & $\mathrm{P}<0.0001$ & $\mathrm{P}=0.667$ & 9.62 & 0.167 & 9.79 & 99.48 \\
\hline PDKTT & 8.37 & 1.19 & 9.00 & 1.11 & $\mathrm{P}<0.0001$ & $\mathrm{P}=0.779$ & 0.217 & 1.13 & 1.347 & 83.89 \\
\hline
\end{tabular}

${ }^{\mathrm{a}}$ Shapiro-Wilk test was conducted to determine if the phenotypic data were normal or not. $\mathrm{p}<0.05$ shows nonnormal distribution.

${ }^{\mathrm{b}}$ Leven's test was conducted to determine if the data among the experiments are homogenous or not. $\mathrm{P}>0.05$ shows equal variance.

$\mathrm{SD}=$ standard deviation

$\sigma_{g}^{2}=$ estimates of genotypic variance

$\sigma_{e}^{2}=$ estimates of environmental variance

$\sigma_{p}^{2}=$ estimates of phenotypic variance

$\mathrm{H}^{2}=$ broad-sense heritability

Table 5. Combined analysis of variance for infection types of wheat accessions to five $P t$ races

\begin{tabular}{|c|c|c|c|c|}
\hline Source & Sum of Squares & df & Mean Square & F \\
\hline REP & 0.522 & 1 & 0.522 & $2.857 \mathrm{~ns}$ \\
\hline Race & 484.756 & 4 & 121.189 & $24.94^{* *}$ \\
\hline Race $\times$ Rep & 5959.959 & 1276 & 4.671 & 25.578 \\
\hline Genotype & 9238.251 & 319 & 28.960 & $158.589^{* *}$ \\
\hline Genotype $\times$ Race & 5959.959 & 1276 & 4.67 & $25.677^{* *}$ \\
\hline Error & 291.994 & 1599 & 0.183 & \\
\hline CV $(\%)$ & 5.35 & & & \\
\hline
\end{tabular}

Table 6. Correlation coefficients between the phenotypic data of 320 wheat accessions evaluated for response to Puccinia triticina $(P t)$ races

\begin{tabular}{|c|c|c|c|c|c|}
\hline & PKTTS & PKTTT & PFTTT & PDKTT & PDTRR \\
\hline PKTTS & 1.00 & $0.481^{* *}$ & $0.705^{* *}$ & $0.561^{* * *}$ & $0.602^{* *}$ \\
\hline PKTTT & & 1.00 & $0.647^{* *}$ & $0.546^{* *}$ & $0.529^{* *}$ \\
\hline PFTTT & & & 1.00 & $0.475^{* *}$ & $0.689^{* *}$ \\
\hline PDKTT & & & & 1.00 & $0.400^{* *}$ \\
\hline PDTRR & & & & & 1.00 \\
\hline
\end{tabular}

\section{Linkage disequilibrium}

223 Linkage disequilibrium decay was examined for the original and imputed datasets for three genomes separately and 224 all chromosomes within each genome. Based on the linkage disequilibrium analysis, the LD declined with the 225 increases in genetic distance. The significant marker pairs at $\mathrm{P}<0.001$ were considered for the study. In general, 226 genome B and D had the highest and lowest marker density, respectively (Table 7 and 8). However, it is more useful 227 to test the LD between each pair of SNPs located on the same chromosome and determine the average of the LD in 228 each genome to identify the pattern of LD in the three genomes. At the genome level in original datasets, for both 229 Landraces and varieties, Genome A had $22.34 \%$ of significant marker pairs with an average $r^{2}$ - value of 0.10 for 
varieties and $31.58 \%$ of significant marker pairs with an average $\mathrm{r}^{2}$ - value of 0.1 for landraces. The maximum marker density for both Landraces and varieties was observed on chromosome 2B with 31387 pair SNPs for varieties and 30754 pair SNPs for landraces. Genome B had 26.39\% of significant markers with an average $\mathrm{r}^{2}$ - value of 0.13 for varieties and $28.71 \%$ of significant markers with an average $\mathrm{r}^{2}$ - value of 0.078 for landraces. Genome D had $24.34 \%$ of significant marker pairs with an average $r^{2}$ - value of 0.12 for varieties and $25.27 \%$ of significant marker pairs with an average $r^{2}$ - value of 0.1 for landraces.

In imputed datasets, the extent of LD for the wheat varieties and landraces was 0.21 and 0.18 , respectively, and the average genetic distance for both of them was about $1.76 \mathrm{cM}$. At the chromosome level, the maximum marker density for both Landraces and varieties was observed on chromosome 3B with 176175 pair SNPs for varieties and 170925 pair SNPs for landraces. In general, the proportion of each A, B, and D genomes from total pairwise varieties SNP markers were estimated at almost 39, 39, and 31\%, respectively, and in the landraces SNP markers approximately 48,45 , and $40 \%$, respectively.

\section{Population structure and kinship matrix}

In order to determine the appropriate number of subpopulations, the number of clusters was plotted $(\mathrm{K})$ against $\Delta \mathrm{K}$. The largest $\Delta K$ value was observed at $K=3$ suggesting the presence of three subpopulations in the tested accessions for both datasets (Figure 1). Using the structure software, the population of 286 accessions was structured into three subpopulations, Sub1, Sub2, and Sub_3 (Figure 2). Sub_1 included 84 accessions, Sub_2 included 75 accessions and Sub_3 included 127 accessions.

Table 7. A summary of observed LD $\left(\mathrm{r}^{2}\right)$ among SNP pairs and the number of significant SNP pairs per chromosomes and genomes of Iranian bread wheat cultivars and landraces in original datasets

\begin{tabular}{|c|c|c|c|c|c|c|c|c|}
\hline \multirow{2}{*}{$\begin{array}{c}\text { Chromoso } \\
\text { me }\end{array}$} & \multicolumn{4}{|c|}{ Cultivar } & \multicolumn{4}{|c|}{ Landrace } \\
\hline & TNSP & $r^{2}$ & $\begin{array}{l}\text { Distance } \\
(\mathrm{cM})\end{array}$ & NSSP & TNSP & $r^{2}$ & $\begin{array}{l}\text { Distance } \\
(\mathrm{cM})\end{array}$ & NSSP \\
\hline $1 \mathrm{~A}$ & 16283 & 6.75189 & 0.109825 & $3917(24.06 \%)$ & 12992 & 11.528 & 0.114653 & $4750(36.53 \%)$ \\
\hline 1B & 22004 & 4.47251 & 0.141322 & $5775(6.25 \%)$ & 25210 & 4.5844 & 0.089915 & $8237(32.67 \%)$ \\
\hline $1 \mathrm{D}$ & 10733 & 10.2787 & 0.184493 & 3367 (31.37\%) & 19042 & 6.3896 & 0.071123 & $4235(22.24 \%)$ \\
\hline $2 \mathrm{~A}$ & 20435 & 5.05017 & 0.123509 & $4915(24.05 \%)$ & 22359 & 4.8757 & 0.114976 & 7734 (34.59\%) \\
\hline $2 \mathrm{~B}$ & 31387 & 4.11067 & 0.12831 & $8386(26.72 \%)$ & 30754 & 4.125 & 0.092202 & $9932(32.29 \%)$ \\
\hline 2D & 13331 & 6.58741 & 0.266553 & $4494(33.7 \%)$ & 15780 & 6.7303 & 0.195837 & $5174(32.78 \%)$ \\
\hline $3 \mathrm{~A}$ & 17793 & 9.80947 & 0.098266 & $3567(20.05 \%)$ & 17858 & 9.1444 & 0.069792 & $4272(23.92 \%)$ \\
\hline 3B & 28610 & 4.62157 & 0.129764 & $7815(27.32 \%)$ & 29925 & 4.4702 & 0.091393 & $9351(31.25 \%)$ \\
\hline $3 \mathrm{D}$ & 4725 & 17.5873 & 0.097313 & $704(14.90 \%)$ & 7601 & 19.707 & 0.090504 & $1628(21.42 \%)$ \\
\hline $4 \mathrm{~A}$ & 15937 & 7.97345 & 0.130939 & $3621(22.72 \%)$ & 15490 & 8.2723 & 0.109944 & $4342(28.03 \%)$ \\
\hline 4B & 8325 & 9.53805 & 0.100295 & $1820(21.86 \%)$ & 8450 & 10.408 & 0.050408 & $1373(16.25 \%)$ \\
\hline $4 \mathrm{D}$ & 3001 & 25.9259 & 0.134246 & $558(18.59 \%)$ & 3171 & 25.715 & 0.10865 & $1088(34.31 \%)$ \\
\hline $5 \mathrm{~A}$ & 15117 & 7.76999 & 0.110108 & $3238(21.42 \%)$ & 16814 & 8.0587 & 0.080919 & $4825(28.70 \%)$ \\
\hline $5 \mathrm{~B}$ & 26207 & 6.39664 & 0.132941 & $7680(29.31 \%)$ & 26766 & 6.3968 & 0.069826 & $6575(24.56 \%)$ \\
\hline $5 \mathrm{D}$ & 5946 & 25.1631 & $0.00939 \mathrm{E}$ & $796(13.39 \%)$ & 6990 & 28.565 & 0.066032 & $1377(19.70 \%)$ \\
\hline $6 \mathrm{~A}$ & 16119 & 7.47835 & 0.106207 & $3117(19.34 \%)$ & 17460 & 7.3983 & 0.118612 & $6784(38.80 \%)$ \\
\hline $6 \mathrm{~B}$ & 21869 & 4.38736 & 0.139339 & $6339(28.99 \%)$ & 24908 & 4.6098 & 0.071623 & $6560(26.64 \%)$ \\
\hline $6 \mathrm{D}$ & 7845 & 18.2414 & 0.0104 & $1358(17.31 \%)$ & 8963 & 17.787 & 0.078422 & $2160(24.10 \%)$ \\
\hline $7 \mathrm{~A}$ & 22236 & 6.02434 & 0.015 & $5304(23.85 \%)$ & 27109 & 6.1406 & 0.107505 & $8369(30.87 \%)$ \\
\hline $7 \mathrm{~B}$ & 24351 & 4.78852 & 0.110689 & $5149(21.14 \%)$ & 25094 & 4.6028 & 0.080258 & $7081(28.22 \%)$ \\
\hline $7 \mathrm{D}$ & 8108 & 19.9858 & 0.0166 & $1794(22.13 \%)$ & 10344 & 19.537 & 0.094395 & $2508(24.24 \%)$ \\
\hline A genome & 123920 & 7.26539 & 0.09912 & $27679(22.3 \%)$ & 130082 & 7.9166 & 0.102343 & $41076(31.6 \%)$ \\
\hline B genome & 162753 & 5.47362 & 0.12609 & $42964(26.4 \%)$ & 171107 & 5.5997 & 0.07795 & $49109(28.7 \%)$ \\
\hline D genome & 53689 & 17.6814 & 0.11827 & $13071(24.4 \%)$ & 71891 & 17.776 & 0.10071 & $18170(25.3 \%)$ \\
\hline Total & 340362 & 10.1401 & 0.11449 & $83714(25 \%)$ & 373080 & 10.430 & 0.09367 & $108355(29 \%)$ \\
\hline
\end{tabular}


bioRxiv preprint doi: https://doi.org/10.1101/2022.02.24.481752; this version posted February 28, 2022. The copyright holder for this preprint (which was not certified by peer review) is the author/funder, who has granted bioRxiv a license to display the preprint in perpetuity. It is made available under aCC-BY 4.0 International license.

TNSP: Total number of SNP pairs, NSSP: Number of significant SNP pairs ( $\mathrm{P}$ value $<0.001)$ 
bioRxiv preprint doi: https://doi org/10.1101/2022.02.24.481752; this version posted February $28,2022$. The copyright holder for this preprint (which was not certified by peer review) is the author/funder, who has granted bioRxiv a license to display the preprint in perpetuity. It is made available under aCC-BY 4.0 International license.

Table 8. A summary of observed LD $\left(\mathrm{r}^{2}\right)$ among SNP pairs and the number of significant SNP pairs per

253 chromosomes and genomes of Iranian bread wheat cultivars and landraces in imputed datasets

\begin{tabular}{|c|c|c|c|c|c|c|c|c|}
\hline \multirow{2}{*}{$\begin{array}{c}\text { Chromoso } \\
\text { me }\end{array}$} & \multicolumn{4}{|c|}{ Cultivar } & \multicolumn{4}{|c|}{ Landrace } \\
\hline & TNSP & $r^{2}$ & $\begin{array}{c}\text { Distance } \\
(\mathrm{cM})\end{array}$ & NSSP & TNSP & $r^{2}$ & $\begin{array}{l}\text { Distance } \\
(\mathrm{cM})\end{array}$ & NSSP \\
\hline $1 \mathrm{~A}$ & 85575 & 0.148218 & 1.737691 & $27125(31.7 \%)$ & 92925 & 0.112764 & 1.596397 & $33515(36.07 \%)$ \\
\hline $2 \mathrm{~A}$ & 118025 & 0.292156 & 0.974187 & $57858(49.02 \%)$ & 123175 & 0.297454 & 0.944378 & $68675(55.75 \%)$ \\
\hline $3 \mathrm{~A}$ & 83675 & 0.159365 & 2.576447 & $25903(30.96 \%)$ & 73525 & 0.136413 & 2.939734 & $28144(38.28 \%)$ \\
\hline $4 \mathrm{~A}$ & 114925 & 0.371766 & 1.513597 & $57774(50.27 \%)$ & 108375 & 0.376224 & 1.612148 & $65451(60.39 \%)$ \\
\hline $5 \mathrm{~A}$ & 59375 & 0.169369 & 2.383461 & $18718(31.53 \%)$ & 58475 & 0.150278 & 2.416511 & $24007(41.06 \%)$ \\
\hline $6 \mathrm{~A}$ & 85175 & 0.181387 & 1.487802 & $29645(34.8 \%)$ & 84425 & 0.181735 & 1.501019 & $40176(47.59 \%)$ \\
\hline $7 \mathrm{~A}$ & 128575 & 0.234215 & 1.344495 & $49426(38.44 \%)$ & 126575 & 0.214252 & 1.365959 & $63357(50.05 \%)$ \\
\hline 1B & 131075 & 0.206251 & 1.063813 & $49717(37.93 \%)$ & 133525 & 0.157517 & 1.041252 & $63803(47.78 \%)$ \\
\hline 2B & 165475 & 0.198105 & 0.859164 & $66129(39.96 \%)$ & 155625 & 0.177663 & 0.913543 & $78536(50.46 \%)$ \\
\hline $3 \mathrm{~B}$ & 176175 & 0.245726 & 0.876581 & $78363(44.48 \%)$ & 170925 & 0.221549 & 0.903978 & $89150(52.16 \%)$ \\
\hline $4 \mathrm{~B}$ & 51325 & 0.1455 & 2.516753 & $13477(26.26 \%)$ & 43025 & 0.1018 & 3.002768 & $12311(28.61 \%)$ \\
\hline $5 \mathrm{~B}$ & 134225 & 0.204683 & 1.433217 & $55633(41.45 \%)$ & 134675 & 0.14301 & 1.449279 & $56285(41.79 \%)$ \\
\hline $6 \mathrm{~B}$ & 158275 & 0.205457 & 0.788418 & $66108(41.77 \%)$ & 164475 & 0.139023 & 0.758663 & $71582(43.52 \%)$ \\
\hline $7 \mathrm{~B}$ & 132875 & 0.156677 & 1.102364 & $41160(30.98 \%)$ & 125875 & 0.129711 & 1.157535 & $50573(40.18 \%)$ \\
\hline $1 \mathrm{D}$ & 37075 & 0.294821 & 4.409069 & $16539(44.61 \%)$ & 40975 & 0.232567 & 3.832101 & $19755(48.21 \%)$ \\
\hline $2 \mathrm{D}$ & 48025 & 0.23446 & 2.2455 & $16275(33.89 \%)$ & 52825 & 0.169092 & 2.048568 & $20548(38.9 \%)$ \\
\hline $3 \mathrm{D}$ & 25475 & 0.143085 & 6.286093 & $5413(21.25 \%)$ & 30125 & 0.174879 & 5.31564 & $11411(37.88 \%)$ \\
\hline $4 \mathrm{D}$ & 10275 & 0.167587 & 10.56621 & $2189(21.3 \%)$ & 10375 & 0.14746 & 10.71346 & $3543(34.15 \%)$ \\
\hline $5 \mathrm{D}$ & 22375 & 0.155406 & 9.337668 & $5503(24.59 \%)$ & 24825 & 0.142184 & 8.361416 & $8953(36.06 \%)$ \\
\hline $6 \mathrm{D}$ & 28475 & 0.142966 & 5.369092 & $6844(24.04 \%)$ & 33475 & 0.14123 & 4.565844 & $12606(37.66 \%)$ \\
\hline $7 \mathrm{D}$ & 34475 & 0.208327 & 5.795738 & $10809(31.35 \%)$ & 40475 & 0.153099 & 4.947296 & $14019(34.64 \%)$ \\
\hline A genome & 675325 & 0.235213 & 1.620443 & $266449(39.4 \%)$ & 667475 & 0.223484 & 1.64269 & $323325(48.4 \%)$ \\
\hline B genome & 949425 & 0.20158 & 1.083656 & $370587(39.0 \%)$ & 928125 & 0.160951 & 1.110386 & $422240(45.5 \%)$ \\
\hline D genome & 206175 & 0.205106 & 5.343207 & $63572(30.83 \%)$ & 233075 & 0.170391 & 4.707401 & $90835(38.97 \%)$ \\
\hline Total & 1830925 & 0.214383 & 1.761302 & $700608(38.3 \%)$ & 1828675 & 0.184979 & 1.76314 & $836400(45.7 \%)$ \\
\hline
\end{tabular}

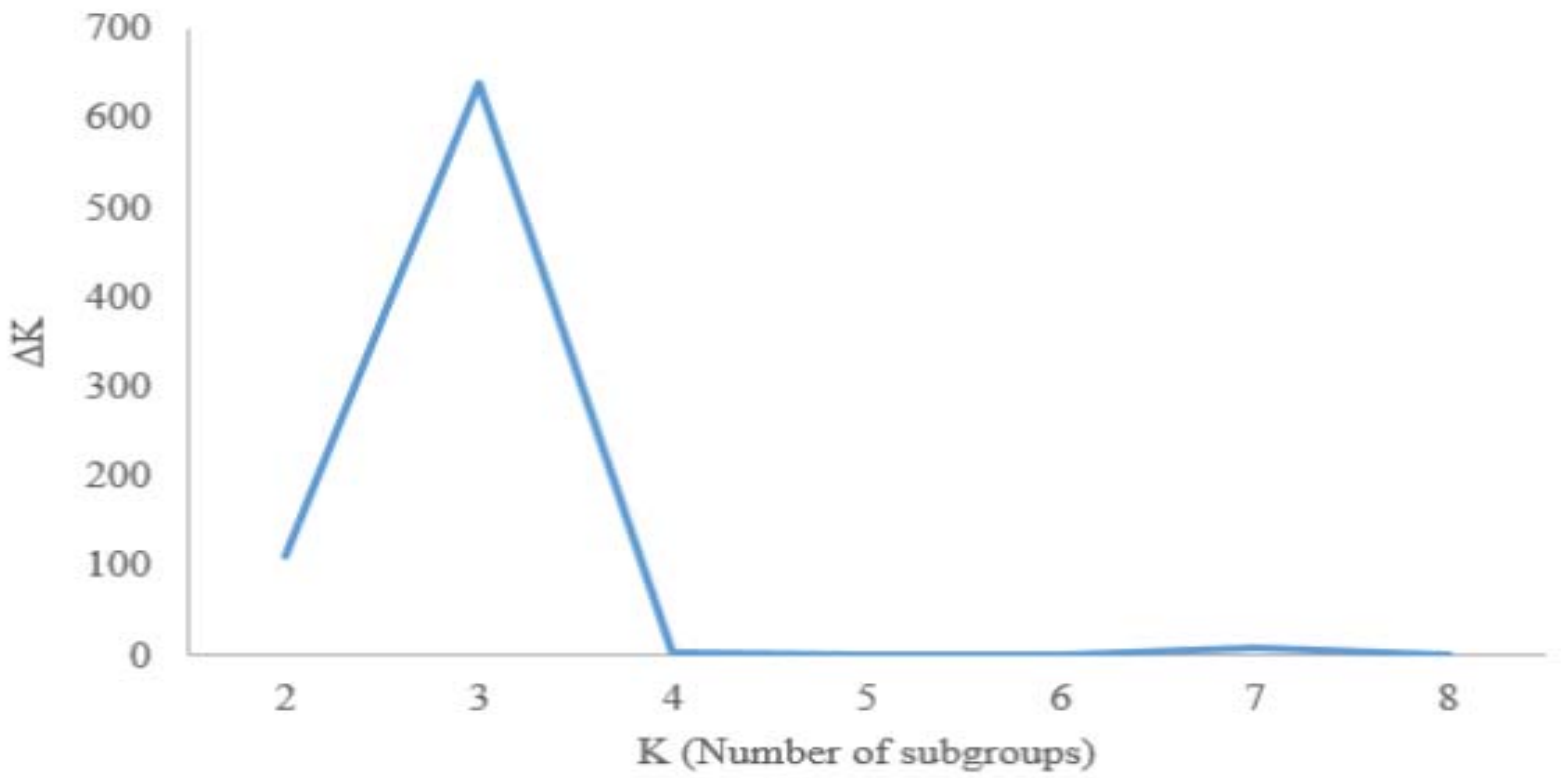

Fig 1 Determination of subpopulations number in wheat genotypes based on $\Delta \mathrm{K}$ values 
To better evaluate population structure and investigate genetic relationships among wheat accessions, PCA of original and imputed SNPs was performed in 286 wheat accessions. For the original datasets, the two major components described a total of $18.59 \%$ of the genetic variance (Figure 3a), whereas it was $23.1 \%$ for the imputed datasets (Figure 3b). Group 1 included 105 accessions with 71 varieties and 34 landraces (63.28\%); Group 2 included the 108 accessions with 102 landraces and 6 varieties (37.76\%); Group 2 included the smallest number of accessions with 73 accessions with 62 landraces and 11 varieties (25.52\%) (Figure 4a). For Original datasets, accessions were also clustered into three main groups. Group 1 included 116 accessions with 6 varieties and 110 landraces; Group 2 included 103 accessions with 85 landraces and 18 varieties; Group 3 included 66 accessions with 3 landraces and 63 varieties (Figure $4 b$ ).

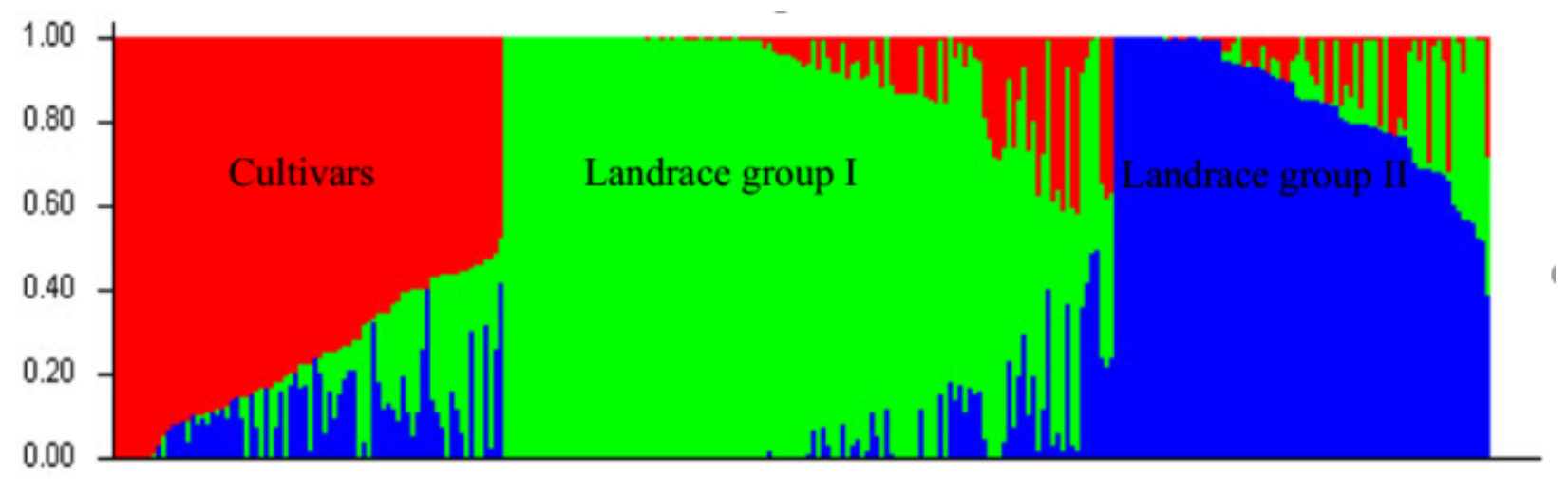

Fig 2 A structure plot of the 286 wheat genotypes and landraces determined by $\mathrm{K}=3$
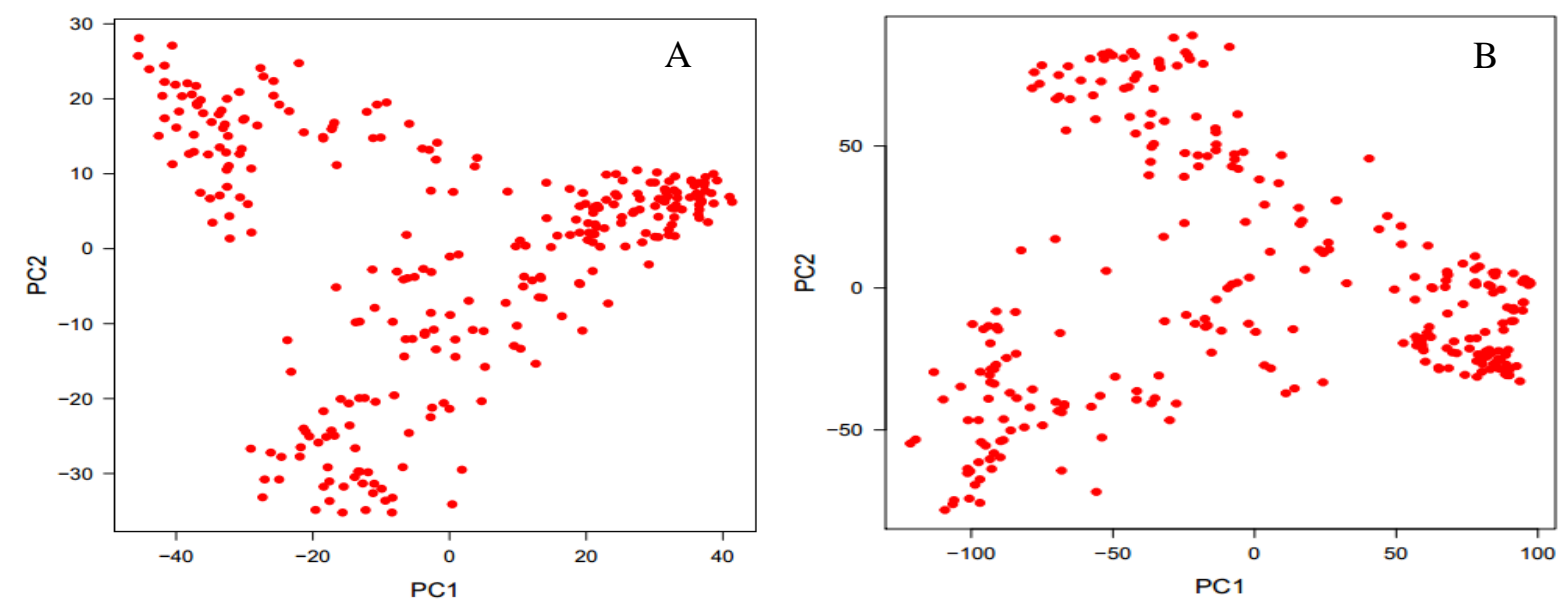

Fig 3 Principal component analysis of Iranian accessions using original SNPs (A), and imputed SNPs.

\section{Marker - trait associations}

GWAS was conducted using infection type data to reveal the association between the phenotypic and genotypic data in the seedling stage. A total of 9043 and 44106 SNP markers were used in GWAS analysis in original and imputed datasets, respectively. Generally, GWAS identified a total of 36 and 390 significant marker-trait associations for original and imputed datasets at a significance level of $-\log 10 \mathrm{P}>3(\mathrm{P}<0.001)$, respectively (Table 9). In original datasets, 7, 4, 18, 3, and 4 significant SNP were detected for resistance to the pathotypes PKTTS, PKTTT, PFTTT, PDTRR, and PDKTT, respectively (Supplementary Table 3). These SNPs were distributed on 1B, 2A, 2B, 3B, 4A, 4B, 4D, 5B, 5D, 6A, 6D, 7B and 7D chromosomes. In imputed datasets, 137, 101, 48, 45 and, 59 significant SNP were detected for resistance to the races PKTTS, PKTTT, PFTTT, PDTRR, and PDKTT, respectively (Supplementary Table 4). These SNPs were distributed on all chromosomes. In imputed datasets, rs10560, rs12690, 
bioRxiv preprint doi: https://doi.org/10.1101/2022.02.24.481752; this version posted February 28, 2022. The copyright holder for this preprint (which was not certified by peer review) is the author/funder, who has granted bioRxiv a license to display the preprint in perpetuity. It is made available under aCC-BY 4.0 International license.

rs12954, rs14228, rs14431, rs17878, rs18054, rs19727, rs21735, rs21939, rs22627, rs23335, rs23336, rs23337,

290
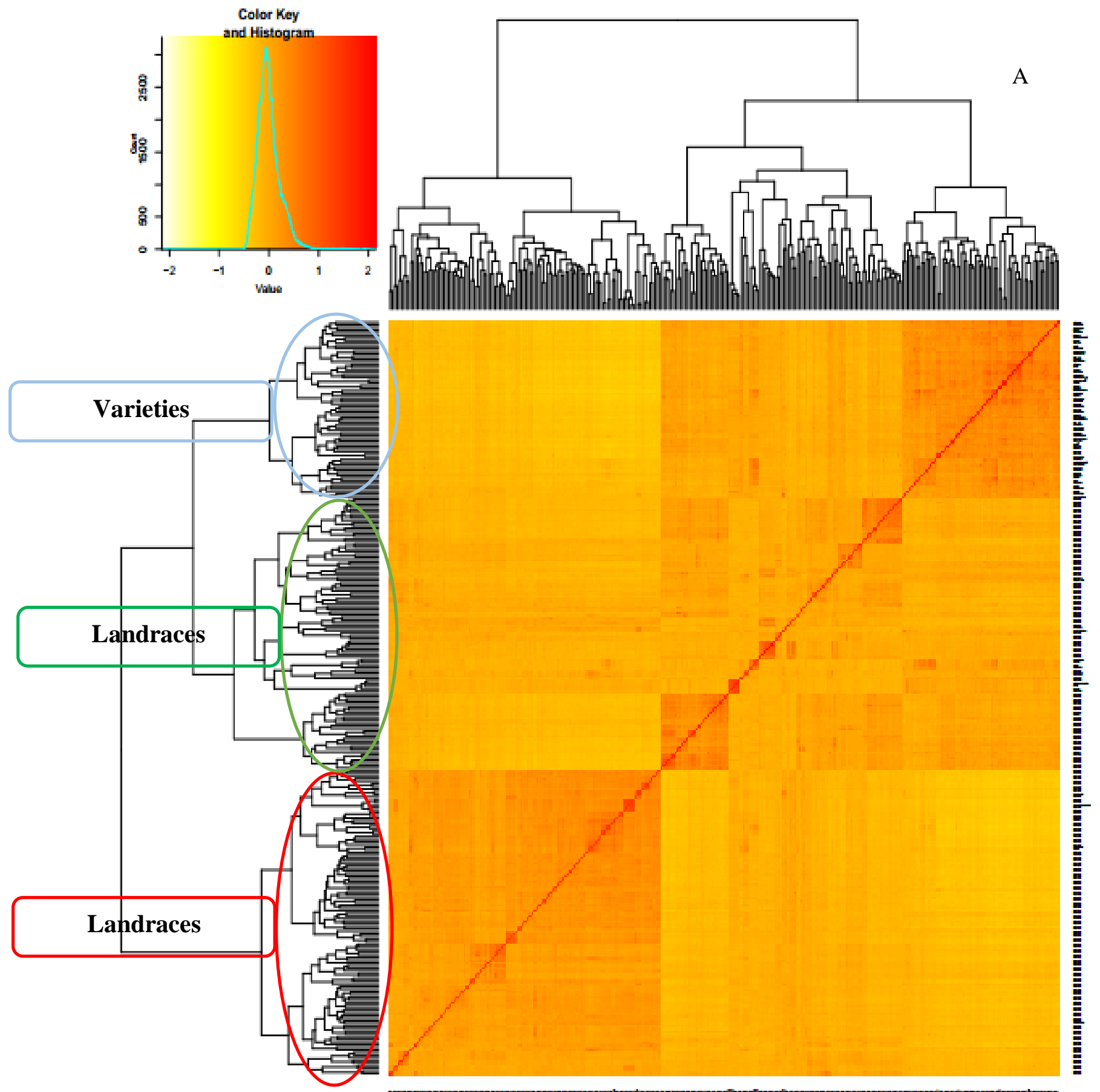
bioRxiv preprint doi: https://doi.org/10.1101/2022.02.24.481752; this version posted February 28, 2022. The copyright holder for this preprint (which was not certified by peer review) is the author/funder, who has granted bioRxiv a license to display the preprint in perpetuity. It is made available under aCC-BY 4.0 International license.
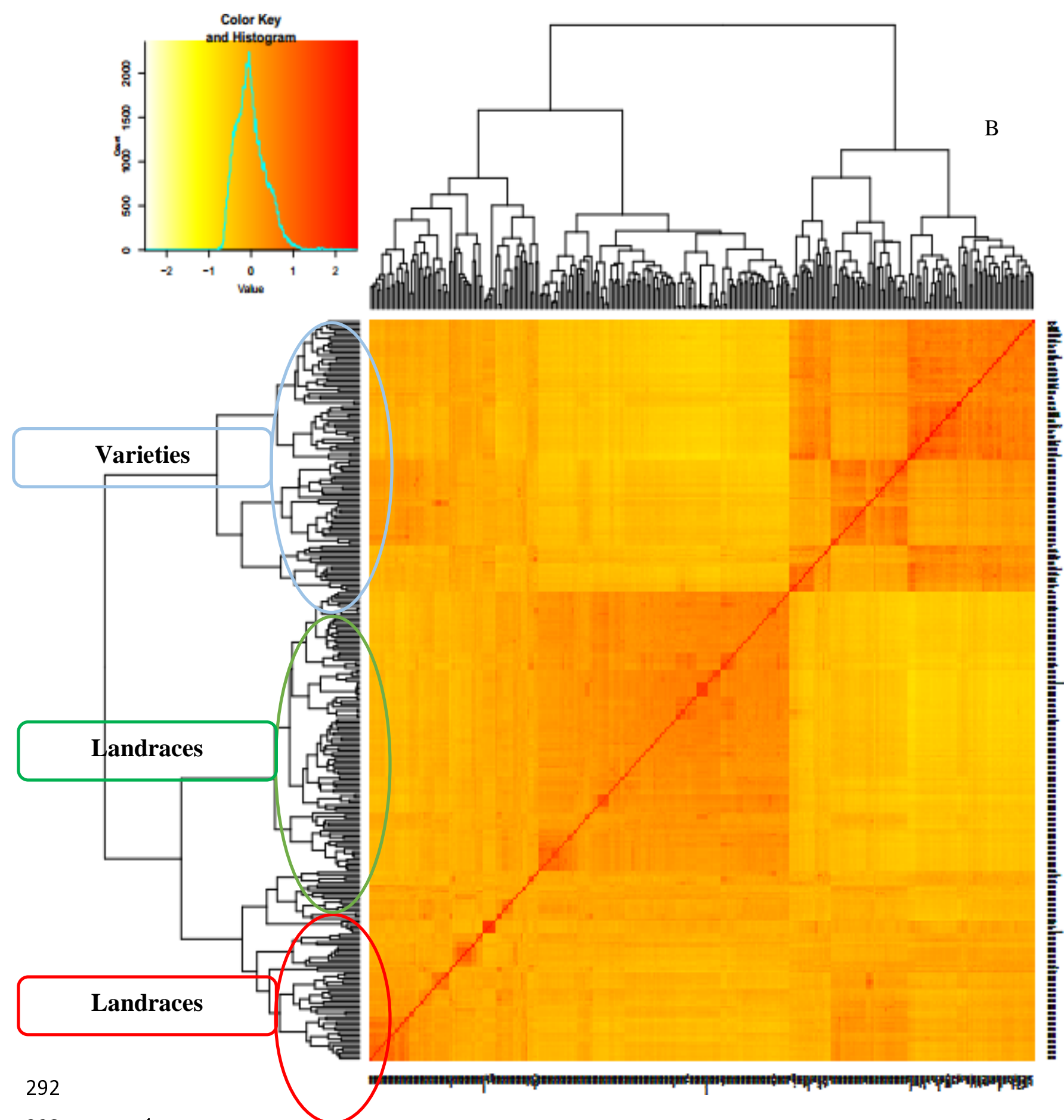

293 Fig 4 Cluster analysis using kiniship matrix of original data (A) and imputed data (B) for Iranian wheat accessions 
rs28358, rs38875, rs44015, rs44160, rs44883, rs45575, rs47218, rs58203, rs59576, rs61015, rs61600, rs62825, rs6313, rs6314, rs64792, rs7195, rs8909, and rs9493 markers were significant for resistance at least two races, while the remaining MTAs were significant to only a single race (Supplementary Table 4). The largest number of associated markers in both datasets was identified on the B genome whereas the smallest number of significant SNPs markers for original and imputed datasets were on the D genome. The major of MTAs in imputed and original datasets were identified on chromosome 2A (52 MTAs) and 1B (6 MTAs), respectively.

Table 9. Number of Marker-trait associations (MTAs) for infection type of studied races in Iranian wheat genotypes

301

\begin{tabular}{|c|c|c|c|c|c|}
\hline Genome & PDTRR & PKTTS & PKTTT & PFTTT & PDKTT \\
\hline \multicolumn{5}{|c|}{ Original datasets } \\
\hline Marker trait association & 4 & 7 & 4 & 18 & 3 \\
\hline Genome A & 1 & 3 & 1 & 2 & 0 \\
\hline Genome B & 1 & 4 & 1 & 11 & 3 \\
\hline Genome D & 1 & 0 & 1 & 5 & 0 \\
\hline Unassembled Chromosomes & 1 & 0 & 1 & 0 & 0 \\
\hline \multicolumn{5}{|l}{ Imputed datasets } \\
\hline Marker trait association & 59 & 137 & 101 & 48 & 45 \\
\hline Genome A & 23 & 53 & 40 & 19 & 21 \\
\hline Genome B & 31 & 72 & 46 & 14 & 18 \\
\hline Genome D & 5 & 12 & 15 & 15 & 3 \\
\hline Unassembled Chromosomes & 0 & 0 & 0 & 0 & 3 \\
\hline
\end{tabular}

The results of FDR $\leq 0.05$ of the GWAS results of both datasets are shown in Table 10. The results showed that there are only two markers for the original datasets in FDR < 0.05 . Two identified markers (rs7087 and rs7088) are associated with the PFTTT race located on chromosome 2B and $6 \mathrm{D}$ at $59.184 \mathrm{cM}$ and $51.214 \mathrm{cM}$, respectively. The results of the imputed datasets showed that there are a total of 17 MTAs in the FDR less than 0.05. All of the MTAs except three MTAs included rs9493, rs62902, and rs62903 (PDKTT), were assigned to PKTTS race. These MTAs were distributed on 1B, 2B, 3A, 3B, 4A, 5B, 5D, 6A, 6B, 6D, 7B and, 7D chromosomes. The maximum of MTAs (4 MTAs) were located on chromosome 1B. The results of Manhattan and QQ-plots of highly associated SNPs for infection type are presented in Figure 5.

\section{Gene annotation}

To gain a deeper understanding of the relationship between SNPs and leaf rust resistance, we examined the gene annotations of these SNPs and studied the effect of SNPs on genes (Tables 15 and 16). The results of gene ontology showed that of the 390 MTAs that we identified using the imputed datasets $24.62 \%$ of them were located within protein-coding genes (Supplementary Table 5). For the original datasets, 6 MTAs (16.67\%) were found within protein-coding genes (Supplementary Table 6). The chromosomal sequence, chromosomal position, the closest wheat gene to them, molecular function and biological processes of these genes, and other information of MTAs are presented in Tables 15 and 16. These genes mostly encode proteins involved in nucleotide binding, hydrolase activity, potassium ion transmembrane transporter activity, hydrolase activity, ATP binding, fatty-acyl-CoA binding, lipid binding, hydrolase activity, protein kinase activity, hydrolyzing O-glycosyl compounds, betafructofuranosidase activity, acting on glycosyl bonds and, protein binding.

\section{Discussion}

The development of new races of leaf rust pathogens is a constant threat to global wheat production. Therefore, it is necessary to investigate additional resistance sources and genes to generate cultivars with effective genes for resistance to leaf rust. GWAS is a potent strategy to recognize QTL associated with complex traits in plants (Alqudah et al. 2020; Hall et al. 2010). GWAS has been successfully applied in wheat gene pools to identify several genes/QTLs that contribute to leaf rust resistance at both the seedling and adult plant stages (Kertho et al. 2015; 
bioRxiv preprint doi: https://doi.org/10.1101/2022.02.24.481752; this version posted February 28, 2022. The copyright holder for this preprint (which was not certified by peer review) is the author/funder, who has granted bioRxiv a license to display the preprint in perpetuity. It is made available under aCC-BY 4.0 International license.

328

331

332

333

334

335

336

337

338

339

340

341

342

343

344

345

346

347

348

349

350

351

352

353

354

355

356

357

358

Aoun et al. 2016; Turner et al. 2017; Riaz et al. 2018). As shown in the present research and previous studies, wheat landraces are a rich
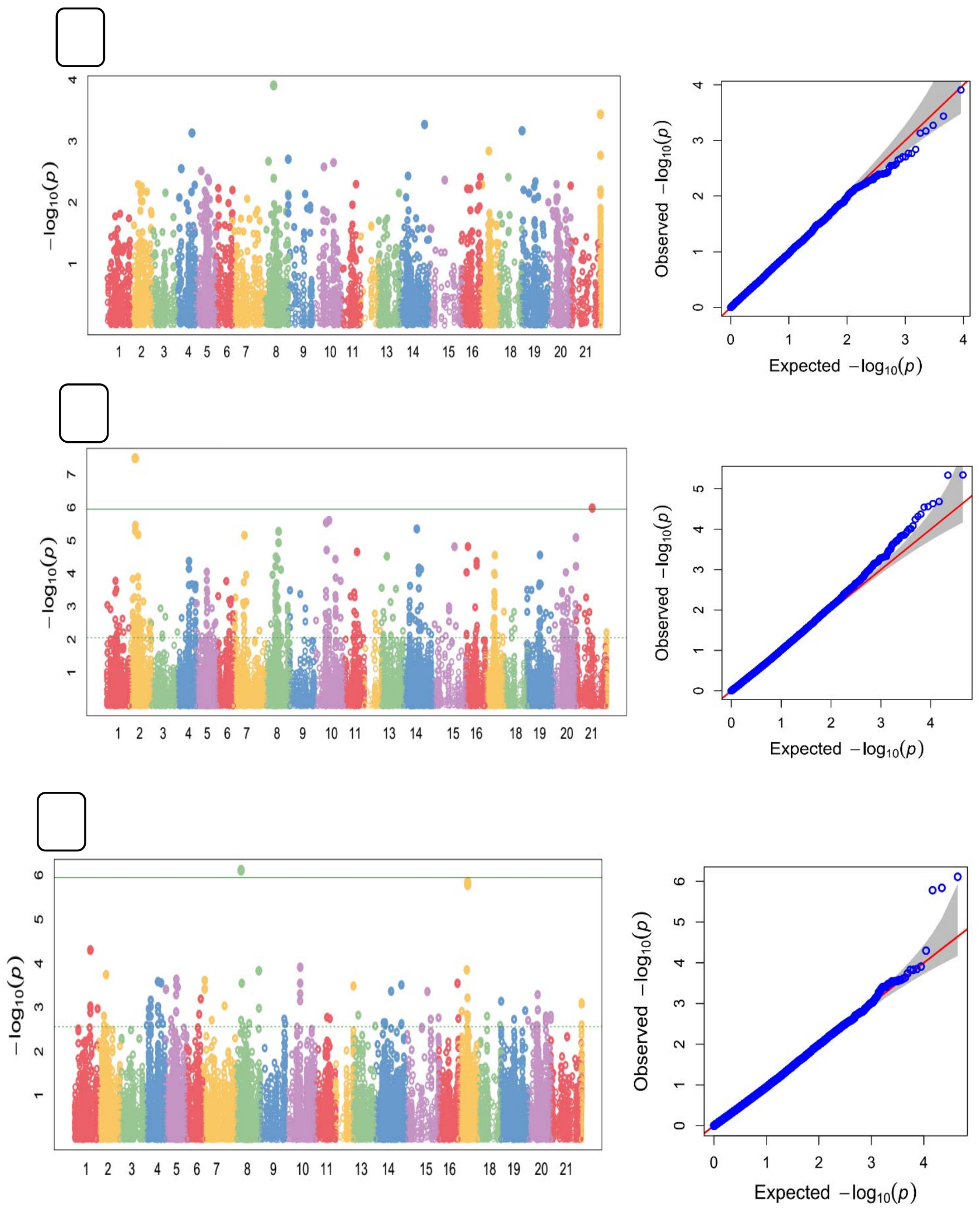
bioRxiv preprint doi: https://doi.org/10.1101/2022.02.24.481752; this version posted February 28,2022 . The copyright holder for this preprint (which was not certified by peer review) is the author/funder, who has granted bioRxiv a license to display the preprint in perpetuity. It is made available under aCC-BY 4.0 International license.

Fig 5 Manhattan and QQ-plots of highly associated haplotypes for Leaf rust. A) PFTTT race, B) PKTTS race, C) PDKTT race. The numbers of 1-22 on $\mathrm{X}$ axis represents chromosomes 1A, 1B, 1D, 2A, 2B, 2D, 3A, 3B, 3D, 4A, $4 \mathrm{~B}, 4 \mathrm{D}, 5 \mathrm{~A}, 5 \mathrm{~B}, 5 \mathrm{D}, 6 \mathrm{~A}, 6 \mathrm{~B}, 6 \mathrm{D}, 7 \mathrm{~A}, 7 \mathrm{~B}, 7 \mathrm{D}$, and unknown respectively. 
Table 10. Summary of marker trait associations (MTAs) discovered significant for resistance to Puccinia triticina (Pt) races PKTTT, PFTTT, PKTTS, PDKTT, and PDTRR at FDR $<0.05$

\begin{tabular}{|c|c|c|c|c|c|c|c|c|c|c|}
\hline SNP & Race & Type data & Allele & Chromosome & Position (cM) & P.value & maf & $\mathrm{R}^{2}$ & pFDR & effect \\
\hline rs7088 & PFTTT & Original & $\mathrm{C} / \mathrm{T}$ & $2 \mathrm{~B}$ & 59.184 & 7.53E-07 & 0.23776 & 0.264 & 0.0068 & 0.16 \\
\hline rs7087 & PFTTT & Original & $\mathrm{C} / \mathrm{T}$ & $6 \mathrm{D}$ & 51.214 & $2.97 \mathrm{E}-06$ & 0.21503 & 0.264 & 0.0134 & 0.16 \\
\hline rs43242 & PKTTS & Imputed & $\mathrm{G} / \mathrm{T}$ & 1B & 30.143 & 3.32E-08 & 0.12237 & 0.348 & 0.0015 & 1.45 \\
\hline rs45675 & PKTTS & Imputed & $\mathrm{T} / \mathrm{C}$ & 1B & 30.711 & $3.51 \mathrm{E}-06$ & 0.08391 & 0.348 & 0.0296 & 1.29 \\
\hline rs45676 & PKTTS & Imputed & $\mathrm{C} / \mathrm{T}$ & $1 \mathrm{~B}$ & 30.711 & $5.20 \mathrm{E}-06$ & 0.08566 & 0.348 & 0.0296 & 1.25 \\
\hline rs43873 & PKTTS & Imputed & $\mathrm{A} / \mathrm{G}$ & $1 \mathrm{~B}$ & 45.006 & $6.78 \mathrm{E}-06$ & 0.07867 & 0.348 & 0.0311 & 1.62 \\
\hline rs62679 & PKTTS & Imputed & $\mathrm{A} / \mathrm{G}$ & $3 \mathrm{~A}$ & 57.649 & 7.04E-06 & 0.09965 & 0.348 & 0.0311 & 0.94 \\
\hline rs28322 & PKTTS & Imputed & $\mathrm{C} / \mathrm{T}$ & $3 B$ & 62.576 & $5.37 \mathrm{E}-06$ & 0.19405 & 0.348 & 0.0296 & 1.09 \\
\hline rs 3229 & PKTTS & Imputed & $\mathrm{C} / \mathrm{T}$ & $3 B$ & 62.576 & $1.18 \mathrm{E}-05$ & 0.18881 & 0.348 & 0.0433 & -1.15 \\
\hline rs10560 & PKTTS & Imputed & $\mathrm{C} / \mathrm{T}$ & $4 \mathrm{~A}$ & 75.832 & $2.50 \mathrm{E}-06$ & 0.07167 & 0.348 & 0.0296 & 1.39 \\
\hline rs21735 & PKTTS & Imputed & $\mathrm{C} / \mathrm{G}$ & $4 \mathrm{~A}$ & 62.152 & 2.92E-06 & 0.08042 & 0.348 & 0.0296 & -1.50 \\
\hline rs6151 & PKTTS & Imputed & $\mathrm{A} / \mathrm{C}$ & $5 B$ & 70.681 & $4.52 \mathrm{E}-06$ & 0.15559 & 0.348 & 0.0296 & -0.91 \\
\hline rs 12954 & PKTTS & Imputed & $\mathrm{A} / \mathrm{G}$ & $5 \mathrm{D}$ & 111.553 & $1.56 \mathrm{E}-05$ & 0.11188 & 0.348 & 0.0492 & 1.00 \\
\hline rs34220 & PKTTS & Imputed & $\mathrm{A} / \mathrm{C}$ & $6 \mathrm{~A}$ & 10.247 & $1.55 \mathrm{E}-05$ & 0.06118 & 0.348 & 0.0492 & 1.18 \\
\hline rs 15705 & PKTTS & Imputed & $\mathrm{A} / \mathrm{G}$ & $7 B$ & 117.414 & $8.23 \mathrm{E}-06$ & 0.35664 & 0.348 & 0.0330 & -0.85 \\
\hline rs42447 & PKTTS & Imputed & $\mathrm{A} / \mathrm{G}$ & $7 \mathrm{D}$ & 83.31 & $1.06 \mathrm{E}-06$ & 0.19755 & 0.348 & 0.0234 & 1.01 \\
\hline rs9493 & PDKTT & Imputed & $\mathrm{A} / \mathrm{G}$ & $3 B$ & 22.764 & 7.73E-07 & 0.09790 & 0.185 & 0.0243 & 0.51 \\
\hline rs62902 & PDKTT & Imputed & $\mathrm{C} / \mathrm{G}$ & $6 \mathrm{~B}$ & 47.831 & $1.45 \mathrm{E}-06$ & 0.13286 & 0.185 & 0.0243 & 0.47 \\
\hline rs62903 & PDKTT & Imputed & $\mathrm{C} / \mathrm{G}$ & $6 \mathrm{~B}$ & 47.831 & $1.65 \mathrm{E}-06$ & 0.13461 & 0.185 & 0.0243 & 0.47 \\
\hline
\end{tabular}

source of genes for resistance to leaf rust (Kertho et al. 2015; Aoun et al. 2016; Turner et al. 2017; Riaz et al. 2018). In the present study, we recognized ten accessions resistant to five $P t$ races that are prevalent in Iran. Nine of these accessions were wheat landraces. Iran is one of the countries in the Fertile Crescent region, which is known as the center origin and diversity of wheat. In addition, previous studies have suggested that the center of origin of P. triticina is probably somewhere in the Fertile Crescent region in southwest Asia (Arthur, 1929), where both sexual and asexual reproduction common (Kolmer et al. 2011). However, possible sexual recombination events are rare in the world (Kolmer et al. 2011). Therefore, this region could provide an opportunity for natural selection and maintenance of resistance accessions. Although wheat landraces may exhibit less desirable agronomic traits, they have been cultivated over many years by local farmers and have been adapted to climate conditions, and have been evolved disease resistance. They also are relatively easy to use in breeding programs compared to alien species (Sehgal et al. 2016). Therefore, the resistant landraces identified in the present study should be useful for developing wheat cultivars resistant to leaf rust.

Pearson correlation coefficients based on infection types revealed the presence of significant correlations for all races in this study (Table 6). These significant correlations were mainly attributed to the similar Pt populations across the country and similar virulence/avirulence profile of these races. According to the virulence/avirulence profile test performed on 20 wheat lines carrying a single $L r$ gene, these five races were virulent to $\operatorname{Lr} 22 \mathrm{~b}, \operatorname{Lrl}, \operatorname{Lr} 3 \mathrm{ka}, \operatorname{Lr} 9, \operatorname{Lr} 10, \operatorname{Lr} 11$, $L r 14 a, L r 20, L r 23, L r 26, L r 33, L r 37$, and $L r 13$ genes. Also, the GWAS panel used in this study probably controls same genomic loci conferring resistance to five 
377

Pt races, and this was further proved by the GWAS analysis results that permitted identification of common QTL, for example, rs38875 marker, conferring

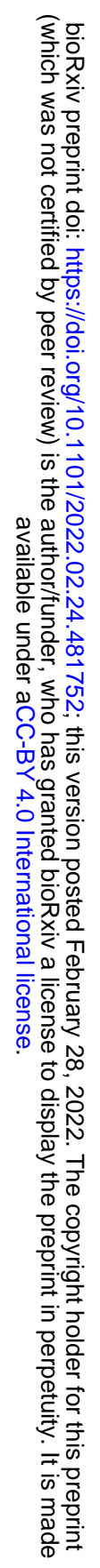


three $P t$ races PFTTT, PDKTT, and, PDTRR (Supplementary Table 4). Also, the rs59576 marker confers resistance to three $P t$ races PFTTT, PDKTT, and, PKTTS. Research findings by Desidrio et al. (2014) and Sapkota et al. (2019) showed that there is a high correlation between the phenotypic data evaluated with several $P t$ breeds, and common genomic loci were identified for resistance of those breeds, which was consistent with the results of this study.

Information about population structure as a confounding factor plays an important role in GWAS analysis because the presence of population structure in the GWAS panel can lead to false association results (Oraguzie et al. 2007). Selection and Genetic drift are two important factors that justify the presence of a subpopulation in a large population (Buckler and Thornsberry 2002). Population structure, kinship matrix, and PCA analysis are widely utilized approach to infer cryptic population structure from genome-wide data such as high-density SNPs. In the present study, population STRUCTURE, PCA analysis, and kinship matrix classified the wheat accessions into three major subpopulations in both the original and imputed datasets. The population structure recognized in this study had a lesser number of subpopulations than several previously reported GWAS studies (Li et al. 2016; Liu et al. 2017; Zegeye et al. 2014), that this due to all of the accessions obtained a small region. The presence of structure in the current population is for two reasons. A significant number of wheat cultivars in this study were obtained from the International Center for Maize and Wheat Improvement (CIMMYT), which is used either directly or as parents in cross-breeding programs leading to new cultivars (Supplementary Table 1). For both original and imputed datasets, population structure showed that CIMMYT advanced lines like Chamran, Darab 2, and Gahar appeared in the same sub-populations along with Iranian cultivars. Also, the role of agro-ecological zones of the country in the formation of three sub-populations and the preservation of this genetic diversity, especially for landraces can be considered.

In order to conduct association studies, the extent of LD and the decay of LD have a great influence on how to analyze association mapping and the SNP markers needed (Flint-Garcia et al. 2003). The results of LD showed that, the LD decay at a higher distance in genome D, than in genomes A and B. Genome B exhibits the lowest level of LD decay. Based on these results, fewer markers are required to detect target QTLs on genome D using GWAS than those required for detecting QTLs on the other genomes (Liu et al. 2017). A comparison of the SNP numbers for each genome reveals that, the D genome had the lowest number of SNPs followed by genomes A and B, respectively. Thus, it can be concluded that our SNPs and wheat population are suitable for GWAS analysis of traits related to target alleles. There is a high chance to identify target QTL with large and small effects based on the high and low LD found across the three genomes (Würschum et al. 2011). Other researchers have reported the same LD decay pattern across all three wheat genomes (Liu et al. 2017; Ayana et al. 2018). A large number of marker pairs were found in the B and A genomes whereas the younger D genome had a smaller number of markers. The same results were reported by others (Berkman et al. 2013; Edae et al. 2015). The higher diversity observed in the A and B genomes could be related to their older evolutionary background and due to gene flow from T. turgidum as opposed to lack of gene flow from Ae. tauschii to bread wheat (Dvorak et al. 2006; Jordan et al. 2015).

Totally 36 and 390 MTAs were significantly (P-value < 0.001) related to leaf rust resistance in Original and imputed datasets, respectively. However, only the relationship of the 19 high-confidence (FDR $\leq 0.05$ ) SNPs across 12 chromosomes with previously identified $L r$ genes/QTL are explained below (Table 10) and the other SNPs are shown in tables 12 and 13. These markers represent 15 loci spread through chromosomes 1B, 2B, 3A, 3B, 4A, 5B, 5D, 6A, 6B, 6D, 7B, and 7D. The consensus map constructed by Maccaferri et al. (2015) was utilized to compare the significant SNPs identified in the study with previously cataloged $L r$ genes and QTLs. Figure 6 shows the schematic display of these resistance loci onto standardized chromosomes with similar length.

\section{Chromosome 1B}

GWAS identified four SNPs rs43242 (30.143cM), rs45675 (30.711cM), rs45676 (30.711cM) and rs43873 (45.006cM) for resistance to the PKTTS race. Nine known $L r$ genes, $L r 26, L r 33, L r 44$ (Dyck and Sykes 1994), Lr46 (Singh 1998), Lr51 (Helguera 2005), Lr55 (Brown-Guedira 2003), Lr71 (Singh et al. 2013), Lr75 (Singla et al. 2017), and LrZH84 (Zhao et al. 2008), and five QTLs, QLr.stars-1BC1 (Li et al. 2016), QLr.cimmyt- 1BS (Rosewarne et al. 2012), QLr.stars-1BS1 (Li et al. 2016), QLr.ifa-1B (Buerstmayr et al. 2014), QLr.stars-1BL2 (Li et al. 2016), are mapped on chromosome 1B. Of these, $\operatorname{Lr} 26, \operatorname{Lr} 44, \operatorname{Lr} 51, \operatorname{Lr} 55$, and $\operatorname{Lr} 71$ were originated from 
Secale cereal, spelta wheat, Triticum speltoides, Elymus trachycaulis, and spelta wheat, respectively (Dyck and Skyes 1994). Since no Secale cereale, spelta, and Triticum speltoides were involved on our GWAS panel, these markers are unlikely to be these genes. Lr46, from spring wheat cultivar CIMMYT Pavon 76 (Singh et al. 1998), Lr75, from wheat cultivar Arina (Schnurbsch et al. 2004), and QLr.ifa-1B, confer APR, and since the experiment was performed in the seedling stage, these markers are unlikely to be genes. $L r Z h 84$, probably derived from wheat cultivar Predgomaia, has been effective in the field for $>30$ years in China. Other QTLs mapped in this region, QLr.stars-1BC1, QLr.cimmyt-1BS, and QLr.stars-1BS1 (Li et al. 2016), showed seedling resistance, and based on consensus map (maccaferi et al. 2015), three identified SNP markers (rs43242, rs45675, and rs45676) have almost same position with this QTLs, so it is likely these markers related to this QTLs. SNP marker rs43873 (45.006cM) were located close to QTL, QLr.stars-1BL2 (Li et al. 2016). This QTL was mapped to be related to response leaf rust resistance in the seedling stage. Therefore, based on the genetic positions of the SNPs, it seems that they are probably associated with the previous QTLs.

\section{Chromosome 2B}

Of the QTLs identified in GWAS in both datasets in FDR $<0.05$, marker rs7088 on $2 \mathrm{~B}$ at $59.184 \mathrm{cM}$, was discovered to be related to resistance to the PFTTT race. $L r$ genes including Lrl3 (Dyck et al. 1966), Lr16 (McCartney et al. 2005), Lr23 (McIntosh and Dyck 1975), Lr48 (Bansal et al. 2008), Lr73 (Park et al. 2014), LrZH22 (Wang et al. 2016), LrA2K (Sapkota et al. 2019), Lr35 (Seyfarth et al. 1999), Lr50 (Brown-Guedira 2003) and three QTL, QLr.cimmyt 2BS (Rosewarne et al., 2012), QLr.hebau-2BS (Zhang et al., 2017), and QLr.uga$2 B S$ (Spakota et al. 2019), were also identified on chromosome 2B. Of these, $\operatorname{Lr} 13$ (originated from Fontana), $\operatorname{Lr} 48$ (Originated from CSP44), and Lr35 are APR genes. As a result, the QTLs detected on chromosome 2B are unlikely to be APR genes. The other genes ie $L r 16, L r 23, L r 73$, and $Q L r$.cimmyt-2BS are seedling resistance genes. Also, Lr50 was derived from T. timopheevii armeniacum, since T. timopheevii armeniacum was included on our GWAS panel, these markers are unlikely to be this gene. According to the consensus map (Maccaferri et al. 2015), these genes are nearly co-located with these QTLs.

\section{Chromosome $3 \mathrm{~A}$}

SNP rs62679 was identified at 57.65cM on chromosome 3A, which carries Lr63 (Kolmer et al. 2010), Lr66 (Marais et al. 2010) genes, and three QTLs, SNPIWA5005, SNPIWA5006, and SNPIWA5786 (Kertho et al. 2015). Lr63 and Lr66 genes were derived from Triticum monococcum and Aegilops speltoides, respectively. Given that no Triticum monococcum and Aegilops speltoides were involved in our GWAS panel, these two genes are unlikely to be rs62679. SNP rs62679 was mapped near a previously mapped QTL, SNPIWA5005, SNPIWA5006, and SNPIWA5786, and therefore, the locus on 3A found in this study can be attributed to these QTLs.

\section{Chromosome 3B}

On chromosome 3B, we identified SNPs rs28322, rs3229, and rs9493 that were related to seedling resistance to PKTTS, PKTTS, and PDKTT, respectively. Other $L r$ gene/QTLs that have been already reported close to rs28322, rs3229, and rs9493 include two $L r$ genes, $L r 27$ (Mago et al. 2011) and $L r 74$ (Bansal et al. 2014) and four QTLs, q3BS-1 (Li et al. 2016), QLr.wpt-3BS (Gerard et al. 2018), Qlr.inra-3Bb.1 (Azzimonti et al. 2014), and QLr.wpt$3 B L$ (Gerard et al. 2018), which in order to determine whether the SNP markers and previously identified genes/QTLs are related, further genetic analysis is required.

\section{Chromosome 4A}

SNPs rs21735 and rs 10560 at $62.15 \mathrm{cM}$ and $75.83 \mathrm{cM}$, respectively, were detected in this research to be associated with resistance to PKTTS race in the seedling stage. Using the consensus map (Maccaferi et al. 2015) the SNP rs21735 is located in the same region as QLr.stars-4AL1. Therefore, it seems that rs21735 is probably associated with QLr.stars-4AL1 ( $\mathrm{Li}$ et al. 2016). Also, based on the consensus map, Marker rs10560 was identified in the vicinity of marker IWA3756 (48.39cM). So, according to the consensus genetic map (Maccaferi et al. 2015) for both SNPs, it appears to be associated to previously identified QTLs, which are effective against the PKTTS race.

Chromosome 5B 
SNP rs6151, associated with PKTTS race in seedling stage, was observed near the genomic region of QLr.stars5BLI (Li et al. 2016) and IWA6383_5BL_138.8 (Turner et al. 2016). Furthermore, the Lrl8 (Carpenter et al. 2017) and Lr52 (Hiebert et al. 2005) leaf rust-resistant genes, originated from T.aestivum, are mapped on the 5BL chromosome. Based on virulence/avirulence profile PKTTS, it has virulence on Lr18 indicating that rs6151is unlikely to be $\operatorname{Lr18}$. Based on the position of QTLs on the consensus map and their origin, the identified marker is likely related to QTLs, QLLr.stars-5BLI and IWA6383_5BL_138.8.

\section{Chromosome 5D}

SNP rs12954 was detected on chromosome 5D at $111.55 \mathrm{cM}$. $L r l$ gene and two QTLs, IWA6289_5DS_0 and IWA1429_5DL3_48.4 are located on chromosome 5D (Turner et al. 2016; Gao et al. 2016). SNP rs12954 is effective for resistance against the PKTTS race. PKTTS race used in this study is virulent to the $\operatorname{Lrl}$ gene indicating that rs1294 is unlikely to be $\operatorname{Lrl}$ (Table 1). IWA6289_5DS_0 is an APR QTL, confer slow rusting resistance, it is unlikely that SNP rs12954 is IWA6289_5DS_0. Also, SNP rs12954 was mapped far from IWA1429_5DL3_48.4, So that they are about $30 \mathrm{cM}$ apart from each other. Therefore, it is likely that the genomic region tagged by SNP rs12954 related to a different QTL that confers resistance to leaf rust during seedling stage.

\section{Chromosome 6A}

The SNP rs34220 was detected significant for resistance to leaf rust on chromosome 6A (Figure 5, 6; Table 10). Three catalogued Lr genes, Lr56, Lr62 (Marais et al. 2008), and Lr64 (Kolmer et al. 2010), and two QTLs, IWA680_6AS and 6A_tl (Gao et al. 2016; Turner et al., 2016) have already been detected on chromosome 6A for leaf rust resistance. Lr56, Lr62, and Lr64 are seedling resistance genes originated from Aegilops sharonensis, Aegilops neglecta and, Triticum dicoccoides, respectively (Somo et al. 2016; Kolmer et al. 2010). Due to the lack of genetic materials that carries these genes in our GWAS panel, it is unlikely that this locus represents $\operatorname{Lr} 56, \operatorname{Lr} 62$, and Lr64. IWA680_6AS and 6A_tl (Turner et al. 2016; Gao et al. 2016), both QTLs identified on chromosome 6A confer APR. According to the genetic locus of gene/QTLs on the consensus genetic map and their origin, SNP identified in this position maybe associated with distinct loci for leaf rust resistance; however, more studies are needed to discover their associations between them.

\section{Chromosome 6B}

On chromosome 6B, we identified two SNPs rs62902 and rs62903 in a same position $(47.83 \mathrm{cM})$, that were related to seedling resistance for PDKTT race. Other $L r$ genes and QTLs that have been previously identified close to these SNPs include Four known genes, Lr3a, Lr3bg, Lr3ka and, Lr9 (McVey and Long, 1993) and, 6B_3, 6B_l, IWA7873, IWA7506, IWA5785, IWA8192, IWA6142, 6B_4, IWA3131, IWA3133, IWA5785, IWA6826, IWA6825, IWA7873, IWA8192, IWA6142, 6B_3, 6B_3, IWA596, IWA3699, and IWA7506 (Kertho et al. 2016) QTLs which requires further genetic studies to discover the association between the gene tagged by rs62903 and identified QTL/genes.

\section{Chromosome 6D}

Marker rs7087 was mapped to the proximity of two previously mapped QTLs on chromosome 6D. According to the consensus map, the genetic map position of rs7087 (42.29) was 8.86 and $11.29 \mathrm{cM}$ from IWA619 and IWA7616, respectively (Kertho et al. 2016). Based on genetic map position, it is likely that rs7087 is correspond to IWA619 or IWA7616 leaf rust resistance QTLs. Further genetic research will be needed to found the association between rs7087 and previously identified QTLs.

\section{Chromosome 7B}

Four previous identified $L r$ genes ( $L r 14 a, L r 14 b, L r 68$, and $L r 72$ ) and a QTL, $Q L r . h w w g-7 B L$, (Lu et al. 2017) were already mapped on chromosome 7B within the region where rs15705 SNP was identified (Figure 6). Among the four $\mathrm{Lr}$ genes previously mapped on 7B, $\operatorname{Lrl} 4 a$ and $\operatorname{Lr} 72$ are from durum wheat (T. turgidum diccocides), and two genes, $L r 68$ and Lr14b are from common wheat (McIntosh et al. 1995; Herrera-Foessel et al. 2012). Lr68 is an APR gene and provides a high level of slow rusting resistance (Herrera-Foessel et al. 2012), this suggests that is it 
unlikely rs 15705 corresponds to Lr68. Marker rs 15705 is a SNP for resistance to PKTTS race and this race is virulent to the $L r 14 a$ gene indicating that rs 15705 is unlikely to be $L r 14 a$. Previously reported QTL for chromosome 7BL, QLr.hwwg-7BL, is an APR gene for leaf rust resistance (Li et al. 2014). Based on the relative length distance in consensus map (Maccaferri et al. 2015), the other QTLs detected on the 7BL $>20 \mathrm{cM}$ are distanced from the detected marker. Further studies, such as utilize SSR markers for GWAS, allelism test or diagnostic marker analysis, can facilitate the determination of the association between rs 15705 and reported gene/QTLs on chromosome 7BL.

\section{Chromosome 7D}

Three known $L r$ genes Lr19, Lr29, and Lr34, and three QTLs, qNV.Lr-7D (Riaz et al. 2017), QLr.hebau-7DS (Zhang et al. 2017), and QLrP.sfr-7DS (Schnurbusch et al. 2004), were already mapped on chromosome 7D within the region where rs42447 was identified (Fig. 6). Lr19, Lr29, and Lr34 were derived from Thinopyron ponticum, Thinopyron ponticum, and T. aestivum Terenzio, respectively. As no genetic material carrying Thinopyron ponticum was used in our GWAS analysis, rs42447 is unlikely to represent $L r 19$ and $L r 29$. Likewise, three other QTL, QTL, qNV.Lr-7D, QLr.hebau-7DS, and QLrP.sfr-7DS, and Lr34 gene are APR, therefore it is unlikely rs 42447 be these gene/QTLs. As a result, rs42447 was found on chromosome 7D where no Pt resistance genes or QTLs had previously been identified. Therefore, the SNP rs42447 identified in genomic region 7D $(83.31 \mathrm{cM})$ appears to be related to novel sources of resistance and could be valuable in breeding programs to enhance resistance to leaf rust.

Annotation of SNP sequences to the genes in Triticum aestivum L. proved our findings that these genomic regions encode proteins that are key components of signaling pathways that are activated in response to biotic and abiotic stresses. In general, these stresses change the expression of related genes in plants, for instance, increase or decrease of essential metabolites, changes in enzyme activity and protein synthesis, also the production of novel proteins (Zhu, 2016). For example, ATP binding protein (Lagudah 2011), ATPase activity (Heath, 1997), catalytic activity (Dmochowska-Boguta et al. 2015), carbohydrate-binding (Wu et al. 2020), nucleic acid binding (Zhang et al. 2019) were reported in earlier studies to be linked to plant diseases resistance. These genes are present in genomic regions associated with resistance traits and can be considered possible candidate genes for resistance against diseases as well as for future cloning of these loci.

\section{Conclusions}

GWAS is an effective strategy for the discovery of molecular markers related to genes and QTLs in wheat. In this research, we assessed a diverse panel of 320 varieties and landraces of Iran for their response to five $P t$ races, PKTTS, PKTTT, PFTTT, PDTRR, and PDKTT, and have been detected ten wheat accessions highly resistant to all five $P t$ races. Totally, GWAS identified 19 QTL highly significant for resistance to leaf rust on chromosomes 1B, 2B, 3A, 3B, 4A, 5B, 5D, 6A, 6B, 6D, 7B, and 7D. Among these, a total of three SNP, on chromosomes 5D, 6A, and $7 \mathrm{D}$, respectively, have been identified on genomic regions where no previously cataloged $L r$ genes has been reported from T. aestivum that represents potential novel loci for leaf rust resistance. Other significant SNPs, have been identified near known $L r$ genes or QTLs, and so, further research is required to approve the detected markers in this study to determine their relationship. These markers can be important targets for marker-assisted selection and fine mapping of functional genes after further validation. 


\section{A}

556

557

558

559

560

561

562

563

564

565

566

567

568

569

570

571

572

573

574

575

576

\section{B}

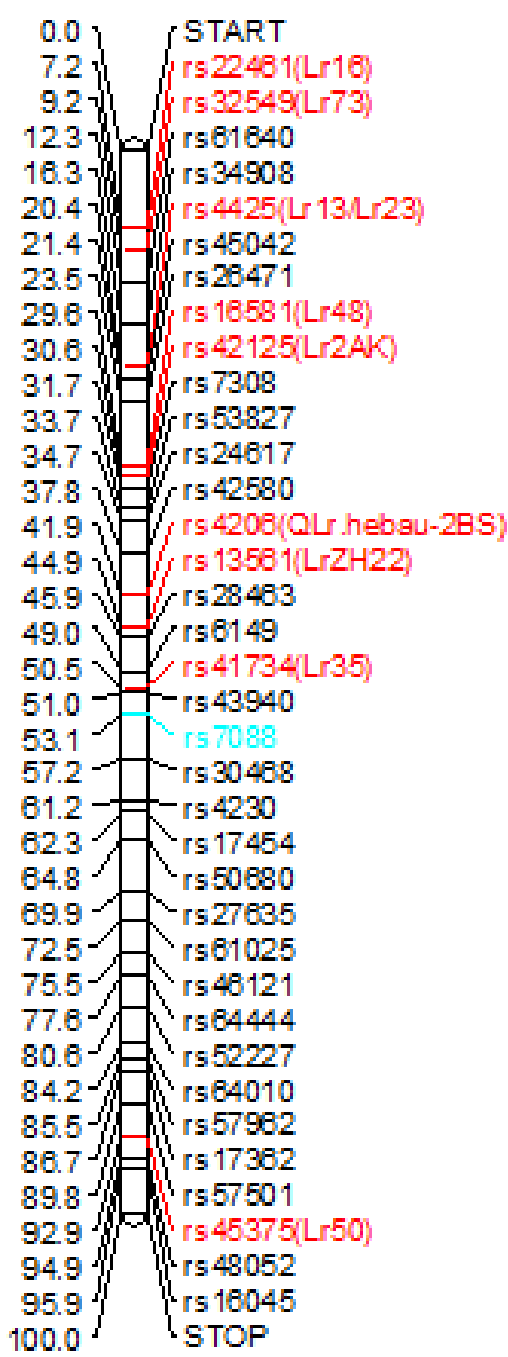

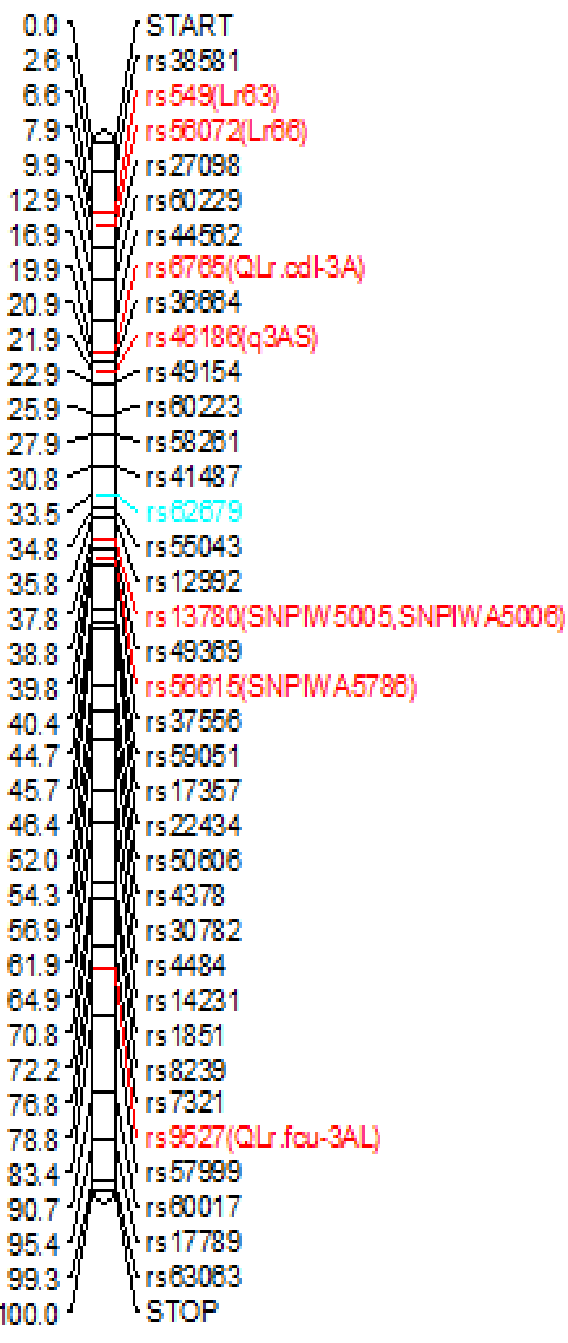




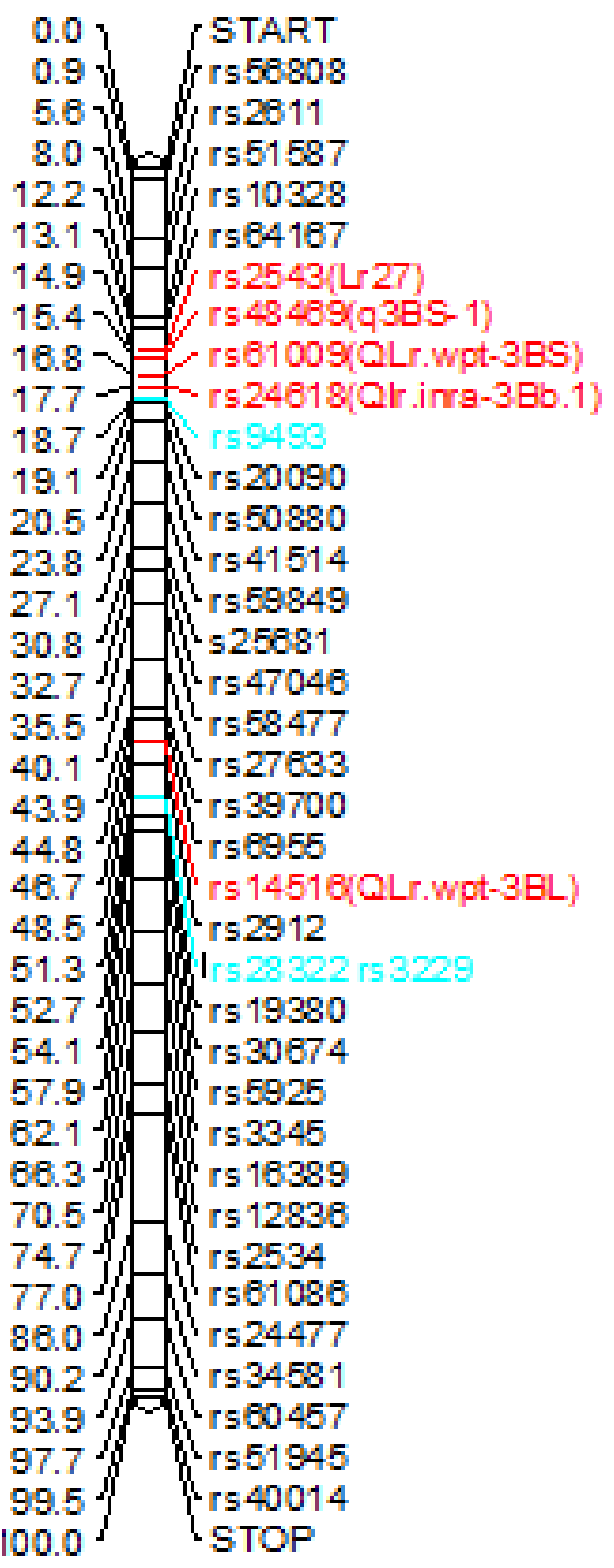

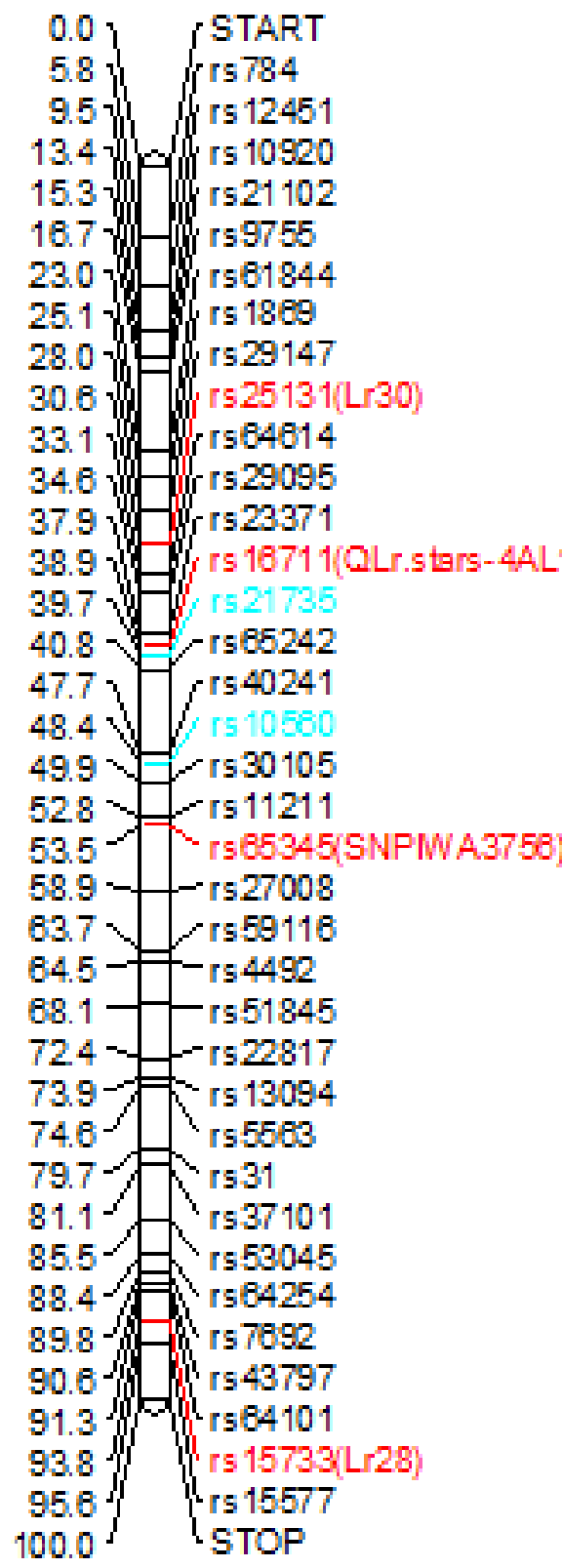

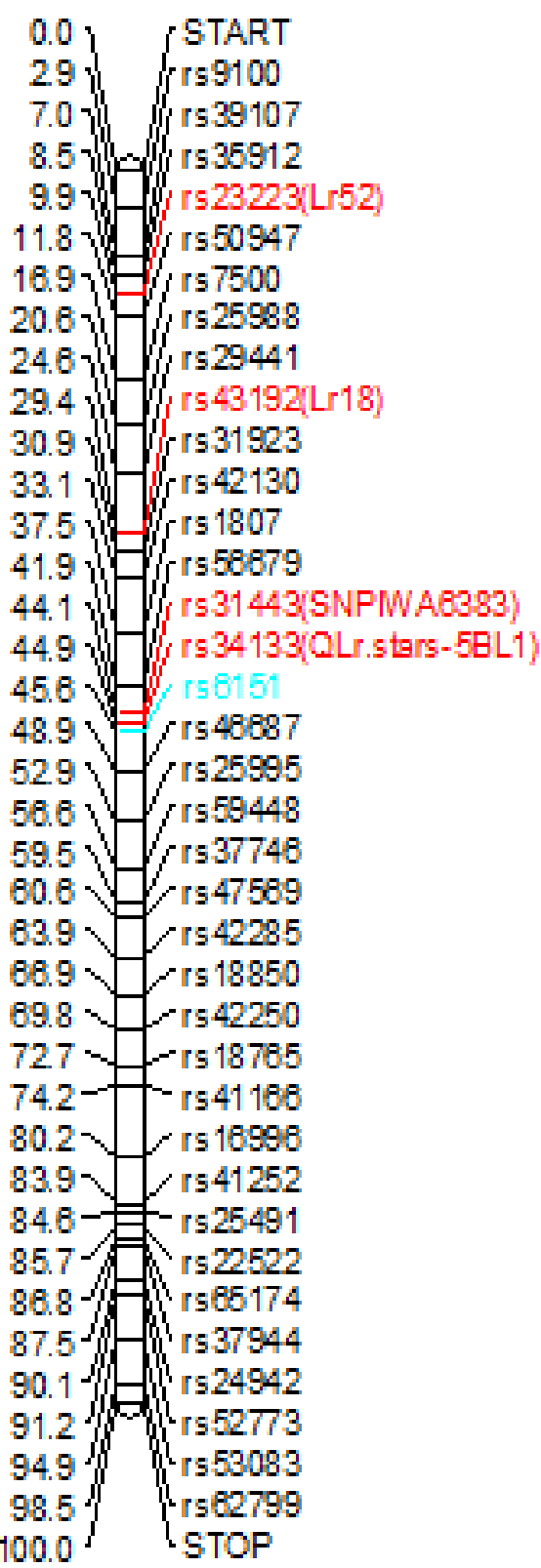




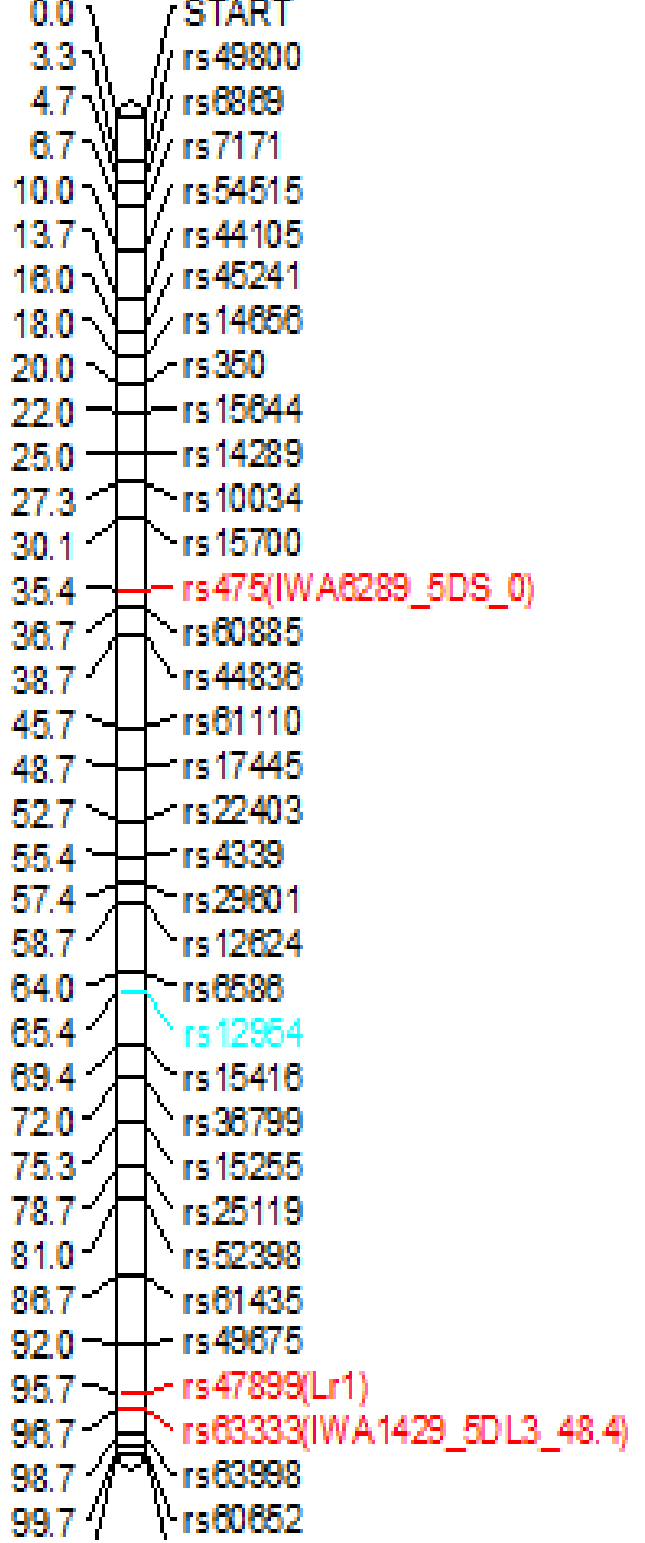

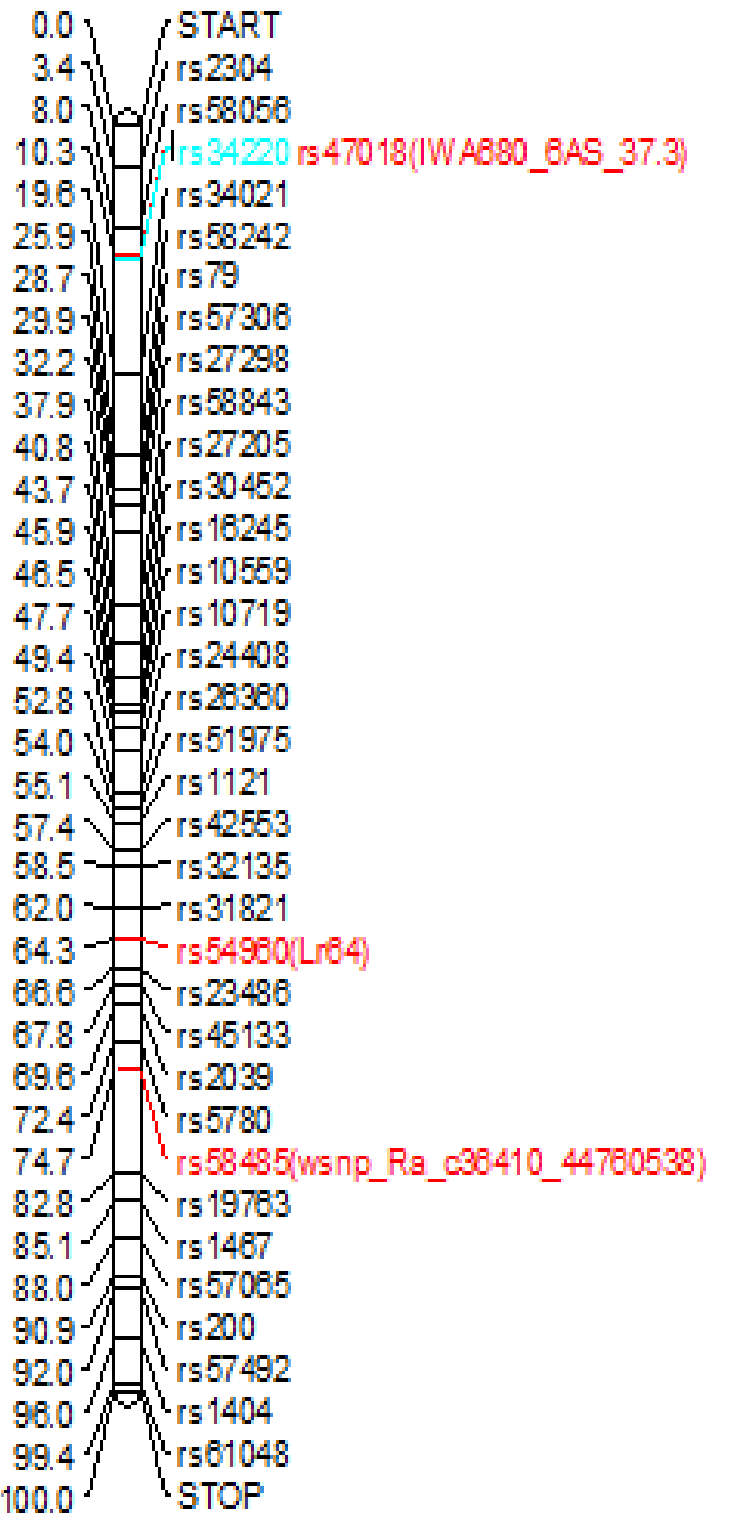

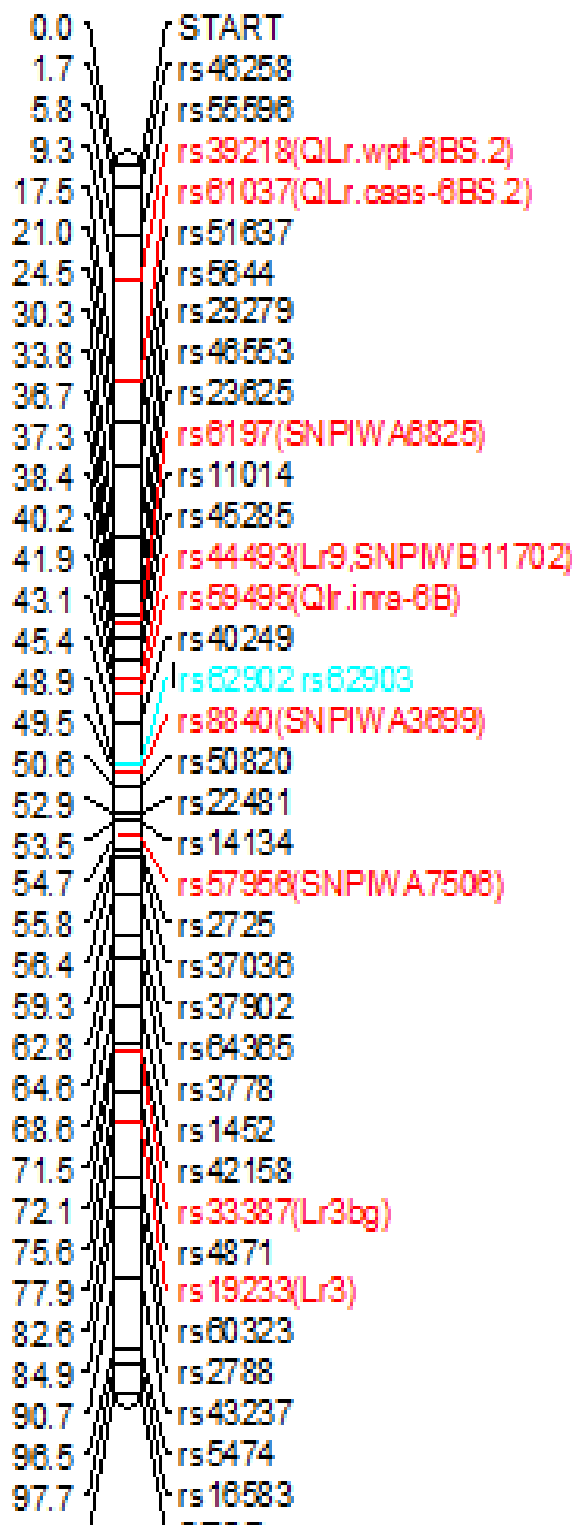


6D

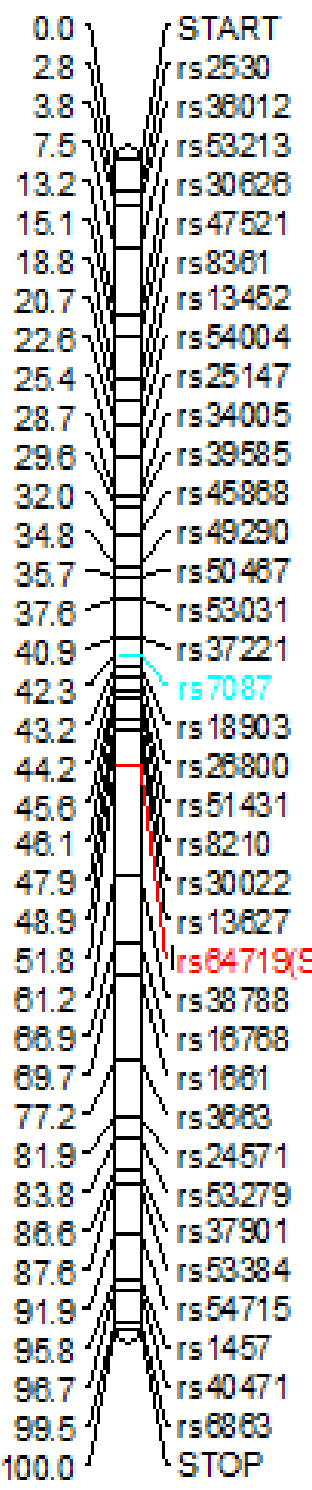

7B

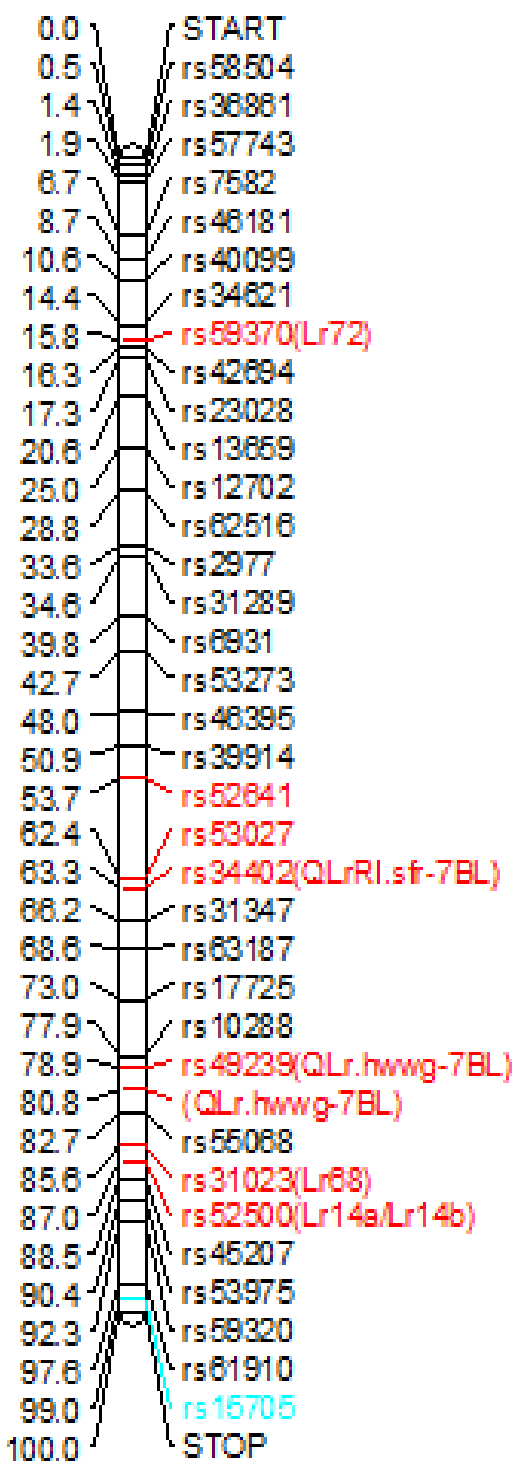

7D

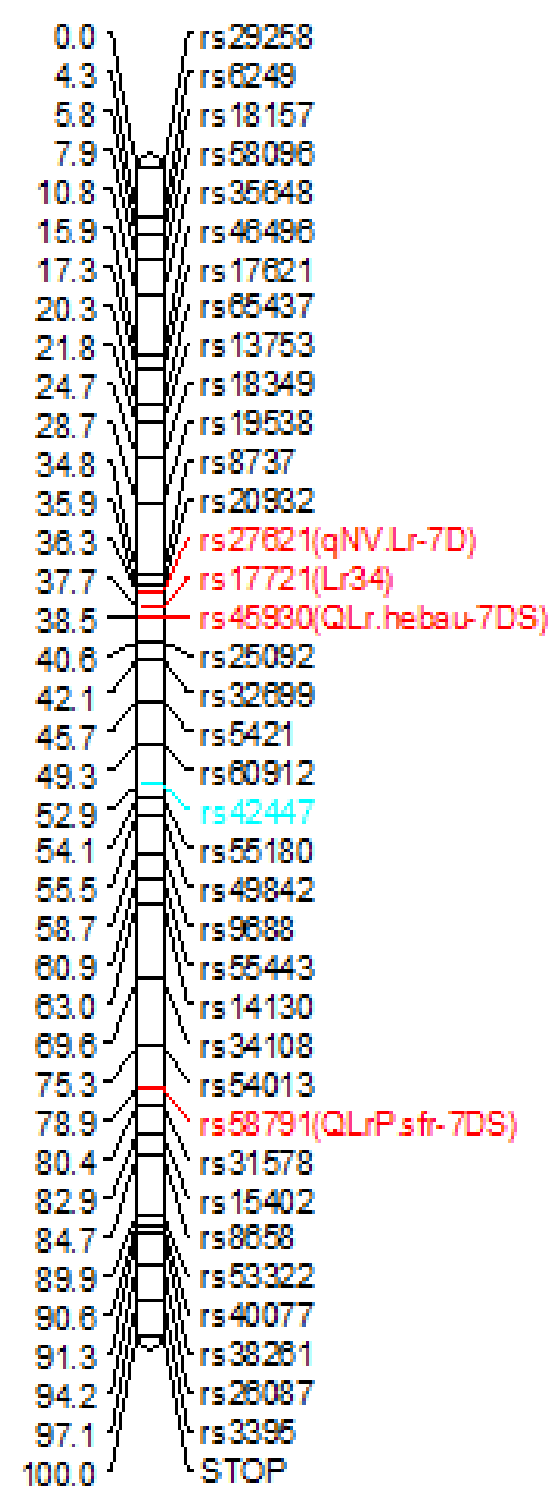




\section{References}

1. Abou-Elwafa S F, \& Shehzad T (2021). Genetic diversity, GWAS and prediction for drought and terminal heat stress tolerance in bread wheat (Triticum aestivum L.). Genet. Resour. https://doi.org/10.1007/s10722-02001018-y

2. Alipour H, Bihamta M R, Mohammadi V, Peyghambari S A, Bai G, \& Zhang G (2017). Genotyping-bysequencing (GBS) revealed molecular genetic diversity of Iranian wheat landraces and cultivars. Front. Plant Sci. https://doi.org/10.3389/fpls.2017.01293

3. Alqudah A M, Sallam A, Baenziger P S, \& Börner A (2020). GWAS: Fast-forwarding gene identification and characterization in temperate Cereals: lessons from Barley-A review. J. Adv. Res. https://doi.org/10.1016/j.jare.2019.10.013

4. Aoun M, Breiland M, Turner M K, Loladze A, Chao S, Xu S, .. \& Acevedo M. (2016). Genome-wide association mapping of leaf rust response in a durum wheat worldwide germplasm collection. The Plant Genome. https://doi: 10.3835/plantgenome2016.01.0008

5. Arthur J C, Kern F D, Orton C R, Fromme F D, Jackson H S, Mains E B, \& Bisby G R (1929). The plant rusts (Uredinales). New York, USA

6. Ayana G T, Ali S, Sidhu J S, Gonzalez Hernandez J L, Turnipseed B, \& Sehgal S K (2018). Genome-wide association study for spot blotch resistance in hard winter wheat. Front. Plant Sci. https://doi.org/10.3389/fpls.2018.00926

7. Bansal U K, Hayden M J, Venkata B P, Khanna R, Saini R G, \& Bariana H S (2008). Genetic mapping of adult plant leaf rust resistance genes Lr48 and Lr49 in common wheat. Theor. Appl. Genet. https://doi 10.1007/s00122-008-0775-6

8. Berkman P J, Visendi P, Lee H C, Stiller J, Manoli S, Lorenc M T, ... \& Edwards D (2013). Dispersion and domestication shaped the genome of bread wheat.

Plant Biotechnol. J. https://doi.org/10.1111/pbi.12044

9. Bradbury P J, Zhang Z, Kroon D E, Casstevens T M, Ramdoss Y, \& Buckler E S (2007). TASSEL: software for association mapping of complex traits in diverse samples. Bioinform. https://doi.org/10.1093/bioinformatics/btm308

10. Brown-Guedira G L, Singh S, \& Fritz A (2003). Performance and mapping of leaf rust resistance transferred to wheat from Triticum timopheevii subsp. armeniacum. Phytopathology. https://doi.org/10.1094/PHYTO.2003.93.7.784

11. Browning B L \& Browning S R (2009). A unified approach to genotype imputation and haplotype-phase inference for large data sets of trios and unrelated individuals. Am. J. Hum. Genet. https://doi.org/10.1016/j.ajhg.2009.01.005

12. Buckler IV E S \& Thornsberry J M (2002). Plant molecular diversity and applications to genomics. Curr. Opin. Plant Biol. https://doi.org/10.1016/S1369-5266(02)00238-8

13. Buerstmayr M, Matiasch L, Mascher F, Vida G, Ittu M, Robert O, ... \& Buerstmayr H (2014). Mapping of quantitative adult plant field resistance to leaf rust and stripe rust in two European winter wheat populations reveals co-location of three QTL conferring resistance to both rust pathogens. Theor. Appl. Genet. https://doi $10.1007 / \mathrm{s} 00122-014-2357-0$

14. Carpenter N R, Griffey C A, Malla S, Chao S, \& Brown-Guedira G L (2017). Mapping Lr18: A leaf rust resistance gene widely deployed in soft red winter wheat. Identification and Mapping of Resistance to Puccinia striiformis and Puccinia triticina in Soft Red Winter Wheat, 88. 
15. Chen X (2020). Pathogens which threaten food security: Puccinia striiformis, the wheat stripe rust pathogen. Food Secur. https://doi.org/10.1007/s12571-020-01016-z

16. Comstock R E \& Robinson H F (1952, August). Genetic parameters, their estimation and significance. In Proceedings of the 6th international Grassland congress, 1: 248-291.

17. Dinh H X, Singh D, Periyannan S, Park R F \& Pourkheirandish M (2020). Molecular genetics of leaf rust resistance in wheat and barley. Theor. Appl. Genet. https://doi.org/10.1007/s00122-020-03570-8

18. Dmochowska-Boguta M, Alaba S, Yanushevska Y, Piechota U, Lasota E, Nadolska-Orczyk A ... \& Orczyk W (2015). Pathogen-regulated genes in wheat isogenic lines differing in resistance to brown rust Puccinia triticina. BMC Genom. https://doi.org/10.1186/s12864-015-1932-3

19. Dvorak J, Akhunov E D, Akhunov A R, Deal K R \& Luo M C (2006). Molecular characterization of a diagnostic DNA marker for domesticated tetraploid wheat provides evidence for gene flow from wild tetraploid wheat to hexaploid wheat. Mol. Biol. Evol. https://doi.org/10.1093/molbev/msl004

20. Dyck P L (1977). Genetics of leaf rust reaction in three introductions of common wheat. Can J Genet Cytol. https://doi.org/10.1139/g77-077

21. Dyck P L \& Sykes E E (1994). Genetics of leaf-rust resistance in three spelt wheats. Can. J. Plant Sci. https://doi.org/10.4141/cjps94-047

22. Dyck P L, Samborski D J \& Anderson R G (1966). Inheritance of adult-plant leaf rust resistance derived from the common wheat varieties Exchange and Frontana. Can. J. Genet. Cytol. https://doi.org/10.1139/g66-082

23. Edae E A, Bowden R L \& Poland J (2015). Application of population sequencing (POPSEQ) for ordering and imputing genotyping-by-sequencing markers in hexaploid wheat. G3. https://doi.org/10.1534/g3.115.020362

24. Evanno G, Regnaut S \& Goudet J (2005). Detecting the number of clusters of individuals using the software STRUCTURE: a simulation study. Mol. Ecol. https://doi.org/10.1111/j.1365-294X.2005.02553.x

25. FAO (2020). FAOSTAT Database. Food and Agriculture Organization of the United Nations, Rome

26. Figueroa M, Hammond-Kosack K E \& Solomon P S (2018). A review of wheat diseases-a field perspective. Mol. Plant Pathol. https://doi.org/10.1111/mpp.12618

27. Flint-Garcia S A, Thornsberry J M \& Buckler IV E S (2003). Structure of linkage disequilibrium in plants. Annu. Rev. Plant Biol. https://doi.org/10.1146/annurev.arplant.54.031902.134907

28. Gao L, Rouse M N, Mihalyov P D, Bulli P, Pumphrey M O \& Anderson J A (2017). Genetic characterization of stem rust resistance in a global spring wheat germplasm collection. Crop Sci. https://doi.org/10.2135/cropsci2017.03.0159

29. Gao L, Turner M K, Chao S, Kolmer J \& Anderson J A (2016). Genome wide association study of seedling and adult plant leaf rust resistance in elite spring wheat breeding lines. PLoS One. https://doi.org/10.1371/journal.pone.0148671

30. Gerard G S, Kobiljski B, Lohwasser U, Börner A \& Simon M R (2018). Genetic architecture of adult plant resistance to leaf rust in a wheat association mapping panel. Plant Pathol. https://doi.org/10.1111/ppa.12761

31. Hall D, Tegström C \& Ingvarsson P K (2010). Using association mapping to dissect the genetic basis of complex traits in plants. Brief. Funct. Genom. https://doi.org/10.1093/bfgp/elp048

32. Heath M C (1997). Signalling between pathogenic rust fungi and resistant or susceptible host plants. Ann. Bot. https://doi.org/10.1006/anbo.1997.0507 
33. Helguera M, Vanzetti L, Soria M, Khan I A, Kolmer J \& Dubcovsky J (2005). PCR markers for Triticum speltoides leaf rust resistance gene $\mathrm{Lr} 51$ and their use to develop isogenic hard red spring wheat lines. Crop Sci. https://doi.org/10.2135/cropsci2005.0728

34. Herrera-Foessel S A, Singh R P, Huerta-Espino J, Rosewarne G M, Periyannan S K, Viccars L ... \& Lagudah E S (2012). Lr68: a new gene conferring slow rusting resistance to leaf rust in wheat. Theor. Appl. Genet. https://doi.org/10.1007/s00122-012-1802-1

35. Herrera-Foessel S A, Singh R P, Lillemo M, Huerta-Espino J, Bhavani S, Singh S ... \& Lagudah E S (2014). Lr67/Yr46 confers adult plant resistance to stem rust and powdery mildew in wheat. Theor. Appl. Genet. https://doi 10.1007/s00122-013-2256-9

36. Hiebert C, Thomas J \& McCallum B (2005). Locating the broad-spectrum wheat leaf rust resistance gene Lr52 $(L r W)$ to chromosome 5B by a new cytogenetic method. Theor. Appl. Genet. https://doi 10.1007/s00122-0051978-8

37. Huerta-Espino J, Singh R P, German S, McCallum B D, Park R F, Chen W Q ... \& Goyeau H (2011). Global status of wheat leaf rust caused by Puccinia triticina. Euphytica. https://doi.org/10.1007/s10681-011-0361-x

38. Jordan K W, Wang S, Lun Y, Gardiner L J, MacLachlan R, Hucl P ... \& Akhunov E (2015). A haplotype map of allohexaploid wheat reveals distinct patterns of selection on homoeologous genomes. Genome Biol. https://doi.org/10.1186/s13059-015-0606-4

39. Kertho A, Mamidi S, Bonman J M, McClean P E \& Acevedo M (2015). Genome-wide association mapping for resistance to leaf and stripe rust in winter-habit hexaploid wheat landraces. PLoS One. https://doi.org/10.1371/journal.pone.0129580

40. Kolmer J (2013). Leaf rust of wheat: pathogen biology, variation and host resistance. Forests. https://doi.org/10.3390/f4010070

41. Kolmer J A (2019). Virulence of Puccinia triticina, the wheat leaf rust fungus, in the United States in 2017. Plant Dis. https://doi.org/10.1094/PDIS-09-18-1638-SR

42. Kolmer J A, Anderson J A \& Flor J M (2010). Chromosome location, linkage with simple sequence repeat markers, and leaf rust resistance conditioned by gene Lr63 in wheat. $\quad$ Crop Sci. https://doi.org/10.2135/cropsci2010.01.0005

43. Kolmer J A, Bernardo A, Bai G, Hayden M J \& Chao S (2018). Adult plant leaf rust resistance derived from Toropi wheat is conditioned by $L r 78$ and three minor QTL. Phytopathology. https://doi.org/10.1094/PHYTO07-17-0254-R

44. Kolmer J A, Ordoñez M E, Manisterski J \& Anikster Y (2011). Genetic differentiation of Puccinia triticina populations in the Middle East and genetic similarity with populations in Central Asia. Phytopathology. https://doi.org/10.1094/PHYTO-10-10-0268

45. Kolmer J A, Su Z, Bernardo A, Bai G \& Chao S (2018). Mapping and characterization of the new adult plant leaf rust resistance gene $L r 77$ derived from Santa $\mathrm{Fe}$ winter wheat. Theor. Appl. Genet. https://doi.org/10.1007/s00122-018-3097-3

46. Kumar S, Bhardwaj S C, Gangwar O P, Sharma A, Qureshi N, Kumaran V V ... \& Bansal U K (2021). Lr80: A new and widely effective source of leaf rust resistance of wheat for enhancing diversity of resistance among modern cultivars. Theor. Appl. Genet. https://doi.org/10.1007/s00122-020-03735-5

47. Lagudah E S (2011). Molecular genetics of race non-specific rust resistance in wheat. Euphytica. https://doi.org/10.1007/s10681-010-0336-3 
48. Li G, Xu X, Bai G, Carver B F, Hunger R, Bonman J M ... \& Dong H (2016). Genome-wide association mapping reveals novel QTL for seedling leaf rust resistance in a worldwide collection of winter wheat. The plant genome. https://doi.org/10.3835/plantgenome2016.06.0051

49. Li H, Singh S, Bhavani S, Singh R P, Sehgal D, Basnet B R ... \& Huerta-Espino J (2016). Identification of genomic associations for adult plant resistance in the background of popular south Asian wheat cultivar, PBW343. Front. Plant Sci. https://doi.org/10.3389/fpls.2016.01674

50. Li Z, Lan C, He Z, Singh R P, Rosewarne G M, Chen X \& Xia X (2014). Overview and application of QTL for adult plant resistance to leaf rust and powdery mildew in wheat. Crop Sci. https://doi.org/10.2135/cropsci2014.02.0162

51. Lipka A E, Tian F, Wang Q, Peiffer J, Li M, Bradbury P J ... \& Zhang Z (2012). GAPIT: genome association and prediction integrated tool. Bioinform. https://doi.org/10.1093/bioinformatics/bts444

52. Liu X P \& Yu L X (2017). Genome-wide association mapping of loci associated with plant growth and forage production under salt stress in alfalfa (Medicago sativa L.). Front. Plant Sci. https://doi.org/10.3389/fpls.2017.00853

53. Long D L \& Kolmer J A. A North American system of nomenclature for Puccinia recondita,Phyto. https://doi: 10.1094/Phyto-79-525.

54. Lu F, Lipka A E, Glaubitz J, Elshire R, Cherney J H, Casler M D, Buckler E S \& Costich D E (2013). Switchgrass genomic diversity, ploidy, and evolution: Novel insights from a network-based SNP discovery protocol. PLoS One. https://doi.org/10.1371/journal.pgen.1003215

55. Maccaferri M, Zhang J, Bulli P, Abate Z, Chao S, Cantu D ... \& Dubcovsky J (2015). A genome-wide association study of resistance to stripe rust (Puccinia striiformis f. sp. tritici) in a worldwide collection of hexaploid spring wheat (Triticum aestivum L.). G3. https://doi.org/10.1534/g3.114.014563

56. Mago R, Tabe L, McIntosh R A, Pretorius Z, Kota R, Paux E ... \& Spielmeyer W (2011). A multiple resistance locus on chromosome arm 3BS in wheat confers resistance to stem rust $(\mathrm{Sr} 2)$, leaf rust $(\mathrm{Lr} 27)$ and powdery mildew. Theor. Appl. Genet. https://doi.org/10.1007/s00122-011-1611-y

57. Marais G F, Bekker T A, Eksteen A, McCallum B, Fetch T \& Marais A S (2010). Attempts to remove gametocidal genes co-transferred to common wheat with rust resistance from Aegilops speltoides. Euphytica. https://doi.org/10.1007/s10681-009-9996-2

58. McCartney C A, Somers D J, McCallum B D, Thomas J, Humphreys D G, Menzies J G \& Brown P D (2005). Microsatellite tagging of the leaf rust resistance gene Lr16 on wheat chromosome 2BSc. $\quad$ Mol. Breed. https://doi.org/10.1007/s11032-004-5948-7

59. McIntosh R A \& Dyck P L (1975). Cytogenetical stndies in wheat. VII Gene Lr23 for reaction to Puccinia recondita in Gabo and related cultivars. Aust. J. Biol. Sci. https://doi.org/10.1071/BI9750201

60. McIntosh R A, Dubcovsky J, Rogers W J, Morris C, Appels R, Xia X C \& Azul B (2013). Catalogue of Gene of Symbols for Wheat: 2013-2014. In Proceedings of the 12th International Wheat Genetics Symposium, 7 September, Yokohama, Japan.

61. McIntosh R A, Wellings C R \& Park R F (1995). Wheat rusts: an atlas of resistance genes. Sydney, Australia

62. McVey D V \& Long D L (1993). Genes for leaf rust resistance in hard red winter wheat cultivars and parental lines. Crop Sci. https://doi.org/10.2135/cropsci1993.0011183X003300060049x

63. Muqaddasi Q H, Brassac J, Ebmeyer E, Kollers S, Korzun V, Argillier O ... \& Röder M S (2020). Prospects of GWAS and predictive breeding for European winter wheat's grain protein content, grain starch content, and grain hardness. Sci. Rep. https://doi.org/10.1038/s41598-020-69381-5 
64. Muqaddasi Q H, Kamal R, Mirdita V, Rodemann B, Ganal M W, Reif J C \& Röder M S (2021). Genome-Wide Association Studies and Prediction of Tan Spot (Pyrenophoratritici-repentis) Infection in European Winter Wheat via Different Marker Platforms. Genes. https://doi.org/10.3390/genes12040490

65. Neumann K, Kobiljski B, Denčić S, Varshney R K \& Börner A (2011). Genome-wide association mapping: a case study in bread wheat (Triticum aestivum L.). Mol. Plant Breed. https://doi.org/10.1007/s11032010-9411-7

66. Nordborg M \& Weigel D (2008). Next-generation genetics in plants. Nature. https://doi.org/10.1038/nature07629

67. Oraguzie N C, Gardiner S E, Rikkerink E H \& Silva H N (2007). Association mapping in plants (p. 278). New York, NY, USA: Springer. https://doi.org/10.1007/978-0-387-36011-9

68. Pang Y, Liu C, Wang D, Amand P S, Bernardo A, Li W ... \& Liu S (2020). High-resolution genome-wide association study identifies genomic regions and candidate genes for important agronomic traits in wheat. Mol Plant. https://doi.org/10.1016/j.molp.2020.07.008

69. Poland J A, Brown P J, Sorrells M E \& Jannink J L (2012). Development of high-density genetic maps for barley and wheat using a novel two-enzyme genotyping-by-sequencing approach. PloS on. https://doi.org/10.1371/journal.pone.0032253

70. Pritchard J K, Stephens M \& Donnelly P (2000). Inference of population structure using multilocus genotype data. Genetics. https://doi.org/10.1093/genetics/155.2.945

71. Quraishi U M, Abrouk M, Murat F, Pont C, Foucrier S, Desmaizieres G ... \& Salse J (2011). Cross-genome map based dissection of a nitrogen use efficiency ortho-metaQTL in bread wheat unravels concerted cereal genome evolution. Plant J. https://doi.org/10.1111/j.1365-313X.2010.04461.x

72. Qureshi N, Bariana H, Kumran V V, Muruga S, Forrest K L, Hayden M J \& Bansal U (2018). A new leaf rust resistance gene Lr79 mapped in chromosome 3BL from the durum wheat landrace Aus26582. Theor. Appl. Genet. https://doi.org/10.1007/s00122-018-3060-3

73. Rafalski A (2002). Applications of single nucleotide polymorphisms in crop genetics. Curr. Opin. https://doi.org/10.1016/S1369-5266(02)00240-6

74. Rahimi Y, Bihamta M R, Taleei A, Alipour H \& Ingvarsson P K (2019). Genome-wide association study of agronomic traits in bread wheat reveals novel putative alleles for future breeding programs. BMC Plant Biol. https://doi.org/10.1186/s12870-019-2165-4

75. Riaz, A., Athiyannan, N., Periyannan, S. K., Afanasenko, O., Mitrofanova, O. P., Platz, G. J., ... \& Voss-Fels, K. P. (2018). Unlocking new alleles for leaf rust resistance in the Vavilov wheat collection. Theor. Appl. Genet. https://doi.org/10.1007/s00122-017-2990-5

76. Riedelsheimer C, Lisec J, Czedik-Eysenberg A, Sulpice R, Flis A, Grieder C ... \& Melchinger A E (2012). Genome-wide association mapping of leaf metabolic profiles for dissecting complex traits in maize. Plos one. https://doi.org/10.1073/pnas.1120813109

77. Rosewarne G M, Singh R P, Huerta-Espino J, Herrera-Foessel S A, Forrest K L, Hayden M J \& Rebetzke G J (2012). Analysis of leaf and stripe rust severities reveals pathotype changes and multiple minor QTLs associated with resistance in an Avocet $\times$ Pastor wheat population. Theor. Appl. Genet. https://doi 10.1007/s00122-012-1786-x

78. Safdar L B, Andleeb T, Latif S, Umer M J, Tang M, Li X ... \& Quraishi U M (2020). Genome-wide association study and QTL meta-analysis identified novel genomic loci controlling potassium use efficiency and agronomic traits in bread wheat. Front. Plant Sci. https://doi.org/10.3389/fpls.2020.00070 
79. Saghai-Maroof M A, Soliman K M, Jorgensen R A \& Allard R W L (1984). Ribosomal DNA spacer-length polymorphisms in barley: Mendelian inheritance, chromosomal location, and population dynamics. PNAS. https://doi.org/10.1073/pnas.81.24.8014

80. Sapkota S, Hao Y, Johnson J, Buck J, Aoun M \& Mergoum M (2019). Genome-Wide Association Study of a Worldwide Collection of Wheat Genotypes Reveals Novel Quantitative Trait Loci for Leaf Rust Resistance. The Plant Genome. https://doi.org/10.3835/plantgenome2019.05.0033

81. Saremirad A, Bihamta M R, Malihipour A, Mostafavi K \& Alipour H (2021). Genome-wide association study in diverse Iranian wheat germplasms detected several putative genomic regions associated with stem rust resistance. Food Sci. Nutr. https://doi.org/10.1002/fsn3.2082

82. Schnurbusch T, Paillard S, Schori A, Messmer M, Schachermayr G, Winzeler M \& Keller B (2004). Dissection of quantitative and durable leaf rust resistance in Swiss winter wheat reveals a major resistance QTL in the Lr34 chromosomal region. Theor. Appl. Genet. https://doi.org/10.1007/s00122-003-1444-4

83. Sehgal D, Singh R \& Rajpal V R (2016). Quantitative trait loci mapping in plants: concepts and approaches. In Molecular breeding for sustainable crop improvement. Springer, Cham. pp. 31-59

84. Shokat S, Sehgal, D, Liu F \& Singh S (2020). GWAS analysis of wheat pre-breeding germplasm for terminal drought stress using next generation sequencing technology. https://doi: 10.20944/preprints 202002.0272.v1

85. Singh D, Mohler V \& Park R F (2013). Discovery, characterisation and mapping of wheat leaf rust resistance gene Lr71. Euphytica. https://doi.org/10.1007/s10681-012-0786-x

86. Singh R P, Mujeeb-Kazi A \& Huerta-Espino J (1998). Lr46: A gene conferring slow-rusting resistance to leaf rust in wheat. Phytopathology. https://doi.org/10.1094/PHYTO.1998.88.9.890

87. Singla J, Lüthi L, Wicker T, Bansal U, Krattinger S G \& Keller B (2017). Characterization of Lr75: a partial, broad-spectrum leaf rust resistance gene in wheat. Theor. Appl. Genet. https://doi 10.1007/s00122-016-2784-1

88. Snedecor GW \& Cochran W G (1989) Statistical Methods. Iowa State University, USA.

89. Somo M, Pirseyedi S M, Cai X, Sharma Poudel R, Chao S \& Marais F (2016). Mapping of Lr56 translocation recombinants in wheat. Plant Breed. https://doi.org/10.1111/pbr.12383

90. Team, R. (2015). RStudio: integrated development for R. RStudio. Inc., Boston, MA, 700.

91. Tibbs Cortes L, Zhang Z \& Yu J (2021). Status and prospects of genome-wide association studies in plants. The Plant Genome. https://doi.org/10.1002/tpg2.20077

92. Turner M K, Kolmer J A, Pumphrey M O, Bulli P, Chao S \& Anderson J A (2017). Association mapping of leaf rust resistance loci in a spring wheat core collection. Theor. Appl. Genet. https://doi 10.1007/s00122-016-2815y

93. VanRaden P M (2008). Efficient methods to compute genomic predictions. Int. J. Dairy Sci. https://doi.org/10.3168/jds.2007-0980

94. Voorrips R (2002). MapChart: software for the graphical presentation of linkage maps and QTLs. J. Hered. https://doi.org/10.1093/jhered/93.1.77

95. Wang C, Yin G, Xia X, He Z, Zhang P, Yao Z ... \& Liu D (2016). Molecular mapping of a new temperaturesensitive gene $L r Z H 22$ for leaf rust resistance in Chinese wheat cultivar Zhoumai 22. https://doi.org/10.1007/s11032-016-0437-3

96. Wang S, Wong D, Forrest K, Allen A, Chao S, Huang B E ... \& Akhunov E (2014). Characterization of polyploid wheat genomic diversity using a high-density 90000 single nucleotide polymorphism array. Plant Biotechnol. J. https://doi.org/10.1111/pbi.12183 
97. Wu J Q, Dong C, Song L \& Park R F (2020). Long-Read-Based de novo Genome Assembly and Comparative Genomics of the Wheat Leaf Rust Pathogen Puccinia triticina Identifies Candidates for Three Avirulence Genes. Front. Plant Sci. https://doi.org/10.3389/fgene.2020.00521

98. Würschum T, Maurer H P, Kraft T, Janssen G, Nilsson C \& Reif J C (2011). Genome-wide association mapping of agronomic traits in sugar beet. Theor. Appl. Genet. https://doi 10.1007/s00122-011-1653-1

99. Yang Y, Chai, Y, Zhang X, Lu S, Zhao Z, Wei D ... \& Hu Y G (2020). Multi-locus GWAS of quality traits in bread wheat: mining more candidate genes and possible regulatory network. Front. Plant Sci. https://doi.org/10.3389/fpls.2020.01091

100.Zargar S M, Raatz B, Sonah H, Bhat J A, Dar Z A, Agrawal G K \& Rakwal R (2015). Recent advances in molecular marker techniques: insight into QTL mapping, GWAS and genomic selection in plants. J Crop Sci Biotechnol. https://doi.org/10.1007/s12892-015-0037-5

101.Zegeye H, Rasheed A, Makdis F, Badebo A \& Ogbonnaya F C (2014). Genome-wide association mapping for seedling and adult plant resistance to stripe rust in synthetic hexaploid wheat. PloS one. https://doi.org/10.1371/journal.pone.0105593

102.Zhang D, Bowden R L, Yu J, Carver B F \& Bai G (2014). Association analysis of stem rust resistance in US winter wheat. PLoS One. doi:10.1371/journa 1.pone. 0103747.

103.Zhang H, Fu Y, Guo H, Zhang L, Wang C, Song W ... \& Ji W (2019). Transcriptome and proteome-based network analysis reveals a model of gene activation in wheat resistance to stripe rust. Int. J. Mol. Sci. https://doi.org/10.3390/ijms20051214

104.Zhang P, Yin G, Zhou Y, Qi A, Gao F, Xia X ... \& Liu D (2017). QTL mapping of adult-plant resistance to leaf rust in the wheat cross Zhou $8425 \mathrm{~B} /$ Chinese Spring using high-density SNP markers. Front. Plant Sci. https://doi.org/10.3389/fpls.2017.00793

105.Zhao X L, Zheng T C, Xia X C, He Z H, Liu D Q, Yang W X ... \& Li Z F (2008). Molecular mapping of leaf rust resistance gene LrZH84 in Chinese wheat line Zhou 8425B. Theor. Appl. Genet. https://doi 10.1007/s00122-008-0845-9

106.Zhu J-K (2016). Abiotic stress signaling and responses in plants. Cell. https://doi.org/10.1016/j.cell.2016.08.029. 